\title{
複断面蛇行河川における洪水流による樹木群の 倒伏・破壊機構と樹木管理への活用
}

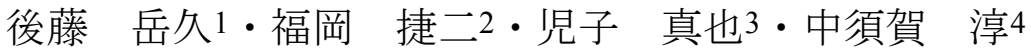 \\ 1学生会員 中央大学大学院 理工学研究科 土木工学専攻（†112-8551 東京都文京区春日1-13-27） \\ E-mail: goto_510@civil.chuo-u.ac.jp \\ 2フェロー 中央大学理工学部特任教授, 中央大学研究開発機構教授（同上) \\ 3正会員 国土交通省 中国地方整備局 岡山河川事務所（干700-0914 岡山県岡山市鹿田町2-4-36） \\ 4正会員 国土交通省 中国地方整備局 河川部河川計画課長 \\ （干730-8530 広島県広島市八丁堀6-30広島合同庁舎2号館）
}

\begin{abstract}
複断面蛇行河川では大洪水時の水位ピーク時に主流が内岸寄りを走り, 内岸砂州が洗掘を受けるため内 岸砂州上の樹木群の倒伏・流失が想定される. 太田川では, 河道内樹木の管理を目的とした樹木調查を行 い，洪水時の水面形の時間変化を観測する準備を行ってきた. 平成17年9月には, 計画高水流量相当の洪 水が発生し, 内岸砂州上の樹木群が倒伏・流失した。本研究では, 観測水面形の時間変化を用いた非定常 二次元洪水流・河床変動解析により, 洪水中の流れと河床変動, 樹木倒伏の関係について検討した。 そし て, 流体力と河床洗掘の観点から，砂州河床上の樹木倒伏・破壊の主な要因は河床洗掘であることを明ら かにした．最後に，本調査・研究から明らかにされた樹木管理の教訓とその活用を示している.
\end{abstract}

Key Words : vegetation destruction, observed temporal changes in water surface profile, unsteady $2 D$ analysis of flood and bed variation, vegetation management

\section{1. 序論}

河川の高水敷上や，蛇行低水路内岸沿いの砂州上，低 水路河岸沿いに樹木の繁茂が見られる. 河道内の樹木群 の存在は，河川環境面から生態系や景観等に望ましい役 割を持つが，治水面からは，河岸保護機能はあるものの， 洪水流流下に対する抵抗要素となり，水位上昇になって 現れることから樹木群の存在は必ずしも望ましいわけで はない. 河道内樹木が流下能力や堤防の安全性に悪影響 を与えるのであれば，樹木の伐採が検討されなければな らない1). 樹木の管理を適切に行うには，治水面からの 検討だけでなく河川生態面からの検討が必要となる。し かし，現在，樹木群の管理について，治水と環境を考慮 した明確な考え方があるわけではなく学術的・技術的に も調査・研究の段階にある. しかし，河川によっては樹 木管理は，治水上，緊急を要する段階にあり，具体的な 方法を見出さなければならない．

樹木の繁茂する河道の洪水時の流下能力の算定や樹木 群の倒伏・非倒伏といった挙動を理解することは，樹木 管理，河川管理上重要である．樹木の繁茂状況が大きく 変化すると河道の流下断面積が変化し, 水位が上昇する ためである.このため洪水時の樹木の挙動を解明する多
くの調查研究が行われている. 福岡・藤田らは, 樹木群 と主流との境界の流速差に起因して生じるせん断力を考 慮して断面内の流速分布を求め, これを取り込んだ準二 次元不等流解析法を用い，樹木群のある流れ場を解いて (る2). 洪水中の樹木の配置の変化や変形が小さい場合 には，樹木群を考慮した準二次元不等流解析法は，かな りの精度で流れ場や流下能力の評価を可能にしており， 河道計画，河道管理に一般的に用いられている3). 国外 では, 横断流速分布と植生の影響を考慮した一次元解析

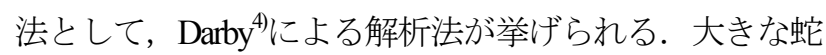
行部や分合流部，河口部等，洪水流の非定常性，二次元 性を考慮しなければならない場合には，非定常平面二次 元解析による検討が有効である. 福岡・渡邊らは, 洪水 流の本質は水面形の時間変化に現れていることに着目し， 樹木の繁茂状況や河道の平面形を考慮に入れ，観測され た水面形の時間变化を解とする非定常平面二次元解析法 により樹木の繁茂する河道の水理量を見積もる解析法を 示している5 の, の, 8). 前野らは旭川の植生調查結果を用い, 洪水時における草本類の挙動を考慮するため, メッシュ 毎に植生の繁茂状況を反映させ，樹木の繁茂する河道に おける非定常二次元解析法の適用性について検討してい る9．前者は洪水時の水面形に着目し，樹木の特徽的な 


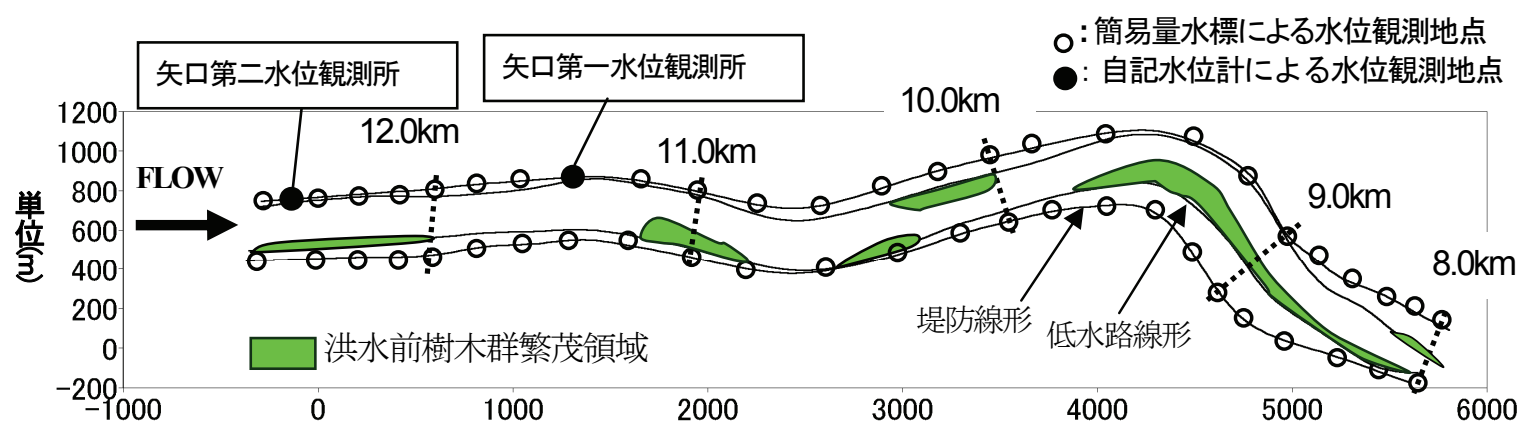

図-1 対象区間樹木繁茂領域と水位観測地点

繁茂区間ごとにその影響を水面形を指標として平均的に 捉え，樹木群のある河道における洪水流の平均的な挙動 の理解とそれを用いた樹木管理について検討している. 後者は，洪水ピーク付近に付着した洪水痕跡の縦断分布 を用い，洪水ピーク付近の流れ場や河床変動特性とその 時生じた植生の挙動を議論し，興味ある結果を得ている。 しかし，洪水の立ち上がりから下降期までの間に，洪水 流と樹木群との間にどのような現象が生じているのかに ついては検討されていない.

大洪水の状況下では，河道の状況や樹木の繁茂状況に よっては，樹木の倒伏や流失も起こることになる.

Armanini $~^{10)}$, Wilson ら ${ }^{11}$ は, 室内実験で樹木の倒伏に よる樹木の抗力係数の変化を調べ，これを洪水流解析に 取り込むことを検討している.

洪水流によって河道内の樹木群が倒伏寸るか否かは, 河道の流下能力を支配する要素となる. 樹木が倒伏すれ ば，河道の流下能力が上昇するが，倒伏しなければ，水 位が上昇し，計画高水位を超えるような危険な状況が生 じる場合が考えられる. しかし，一般的に樹木の倒伏は 洪水後にしか判定できない，樹木の倒伏には，外力とし ての洪水流量や水位のほかに, 樹木群の特性, 河道線形, 断面形, 河床勾配や河床材料などの河道特性が関係し, さらに樹木群がどのような位置にどのような種類と規模 で繁茂しているか等の条件が密接に関係し，同一河川で あっても樹木群の倒伏条件が一律には定まらない.

樹木倒伏についてのこれまでの調查研究は, 主に一本 立ちの樹木の倒伏について, 樹木に働いたと考えられる 外力モーメントを求め, これと樹木の引き倒し試験から 求められた樹木の倒伏モーメントを比較検討し, 倒伏外 力の推定が行われてきた. 例えば，北川・島谷らはゴミ の付着と樹木の倒伏の関係，倒伏の形態を現地調査によ り検討している ${ }^{12)}$. 渡邊・市川らは流水による土中水分 の増加と根の支持力低下の関係を示し ${ }^{13)}$, 服部・瀬崎ら は千曲川で生じたハリエンジュの倒伏・流失について, 河岸侵食と河床低下の視点から樹木の倒伏機構について 検討している ${ }^{14)}$ 。清水らは移動限界碩径と倒伏限界モ一

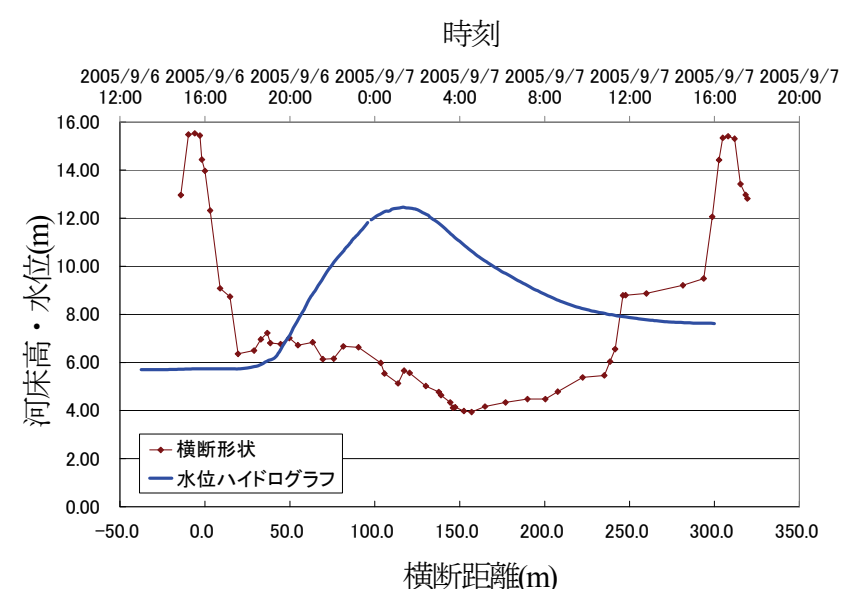

図-2 矢口第一水位観測所における横断形状と 水位ハイドログラフ

メントを用い，樹木倒伏の要因が河床の攪乱であるとし ている ${ }^{15)}$ ，八木澤・田中らは，樹木倒伏は樹木が繁茂す る場所の河床の状況に関係するとの考えにより，樹木の 倒伏モーメントを検討し ${ }^{10}$ ，樹木が倒伏する時の底面せ ん断力から樹木の倒伏が河床の洗掘に起因していると推 定している ${ }^{17)}$. 一般に, 洪水中の樹木倒伏が河川管理上 特に重要になるのは, 密生した樹木群の洪水流に対する 集団としての挙動であり, 集団としての樹木群の倒伏は 一本立ちの樹木の倒伏とは異なる機構が考えられる.す なわち, 引き倒し試験結果とは異なる機構で樹木群の破 壊が進むことが考えられる. 汎用されている倒伏モ一メ ントによる算定法 ${ }^{31}$ は，一つの方法ではあるが河川管理 上からは, より現実に近い算定法の構築が望まれる.

洪水時に，どのような場所で，どのような繁茂形態の 樹木群が，いわ，どの程度の洪水外力で倒伏が起こった のかを明らかにするためには, 洪水後に倒伏した樹木を 調べるという偶然性に頼るのではなく, 大きな洪水に対 して計画的に樹木群の挙動観測を行い，また解析を意識 したデータ収集を行うことが大切である.

太田川では，近年河道内に樹木が繁茂しており，特に 下流域では流下能力及び樹木管理の観点から大きな課題 になっていた．著者らは，大洪水時の樹木群の挙動を明 


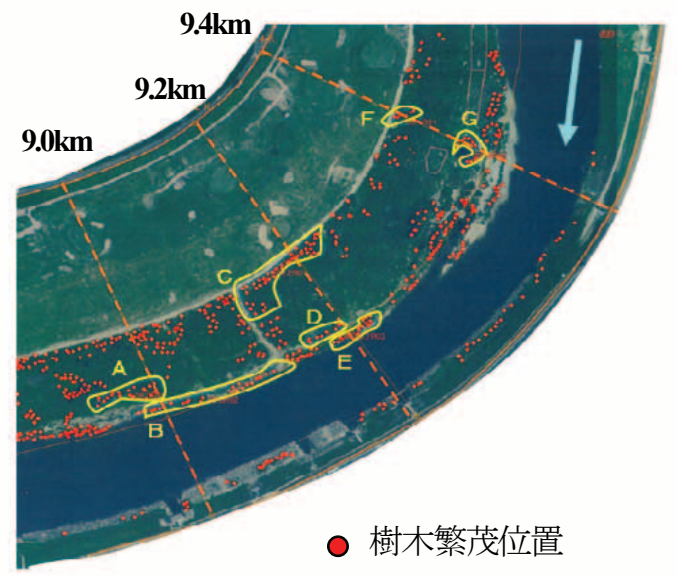

図-3 樹木繁茂状況（9.0-9.4km）（平成15年）

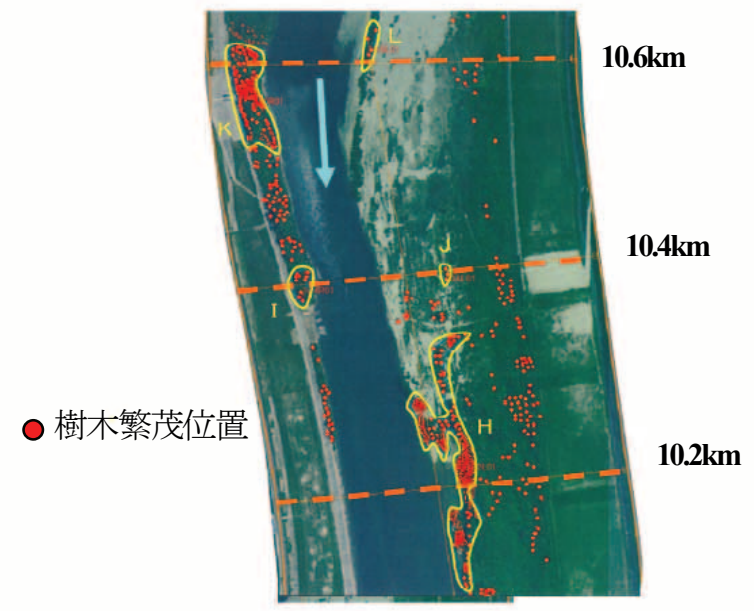

図-4 樹木繁茂状況(10.2-10.6km)（平成15年）

表-1 砂州上の樹木特性

\begin{tabular}{|c|c|c|c|c|c|c|}
\hline & 樹種 & 繁茂面積 $\left(\mathrm{m}^{2}\right)$ & 胸高直径 $(\mathrm{cm})$ & 樹高 $(\mathrm{m})$ & 枝下高 $(\mathrm{m})$ & 樹木密度 $\left(\right.$ 本 $\left./ \mathrm{m}^{2}\right)$ \\
\hline $\mathrm{A}$ & マグワ & 926.0 & 5.1 & 5.0 & 1.1 & 0.092 \\
\hline $\mathrm{B}$ & マグワ & 1046.8 & 5.6 & 5.7 & 1.4 & 0.210 \\
\hline $\mathrm{C}$ & マグワ & 1879.0 & 7.1 & 5.1 & 0.8 & 0.102 \\
\hline $\mathrm{D}$ & マグワ & 317.4 & 6.0 & 4.1 & 0.7 & 0.047 \\
\hline $\mathrm{E}$ & マグワ & 473.2 & 4.8 & 4.1 & 0.8 & 0.224 \\
\hline $\mathrm{F}$ & マグワ & 346.1 & 10.0 & 4.3 & 1.0 & 0.026 \\
\hline $\mathrm{G}$ & オオタチヤナギ & 275.1 & 4.3 & 4.1 & 0.1 & 0.174 \\
\hline $\mathrm{H}$ & マグワ & 4416.0 & 6.5 & 4.4 & 0.7 & 0.190 \\
\hline $\mathrm{I}$ & アカメヤナギ & 438.2 & 9.0 & 5.5 & 0.3 & 0.137 \\
\hline $\mathrm{J}$ & マグワ & 104.7 & 8.3 & 3.8 & 0.9 & 0.086 \\
\hline $\mathrm{K}$ & アカメヤナギ & 2396.0 & 10.2 & 8.0 & 1.1 & 0.143 \\
\hline $\mathrm{L}$ & アカメヤナギ & 369.4 & 5.0 & 5.0 & 0.0 & 0.103 \\
\hline $\mathrm{M}$ & エノキ & 2396.0 & 11.3 & 6.8 & 1.0 & 0.155 \\
\hline $\mathrm{N}$ & アカメヤナギ & 405.5 & 19.8 & 6.3 & 0.1 & 0.086 \\
\hline $\mathrm{O}$ & アカメヤナギ & 7665.0 & 6.7 & 10.7 & 3.3 & 0.288 \\
\hline $\mathrm{P}$ & アキニレ & 1162.4 & 12.6 & 6.2 & 1.3 & 0.075 \\
\hline
\end{tabular}

図-5＼cjkstart樹木繁茂状況(10.8-11.2km)（平成15年）

らかにし，河道内の樹木管理に資する有効な情報を得る ことを目的に，平成 15 年から樹木の繁茂形態や樹木特 性をあらかじめ調べていた ${ }^{18,19)}$. 同時に，大洪水時の樹 木群に作用寸る洪水流の外力算定や樹木群の挙動の解明 に必要な水面形の時間変化を観測し，樹木群の倒伏が起 こったとき，その挙動が水面形に現れるとの予想のもと に，水面形の時間変化を検討出来るように簡易水位計を 対象区間に密に配置し，観測の準備を行っていた ${ }^{18), 19)}$

(図-1）。平成 17 年 9 月に図-2 に示寸ような計画高水 位に匹敵するような戦後最大規模 $\left(7,200 \mathrm{~m}^{3} / \mathrm{s}\right)$ の洪水が発 生し, 樹木群の大規模な倒伏が生じた. 以下に平成 17 年 9 月洪水の調查・検討結果を報告し, 洪水流と樹木群 の挙動及び樹木倒伏のメカニズムを明らかにする.さら に樹木管理に必要な調査法及び得られた教訓を示寸。

\section{2. 太田川の河道特性}

\section{(1) 洪水流及び河道内樹木の観測状況}

図-1は観測と解析対象区間である太田川 $18.0 \mathrm{~km} \sim 13.0 \mathrm{~km}$
区間の河道平面図を示寸．この区間は，近年砂州上の樹 林化が顕著になり，洪水流下能力が低下している区間で ある. 矢口第一水位観測所・矢口第二水位観測所に自記 水位計が設置されており，これに加え簡易水位計を縦断 的に $200 \mathrm{~m}$ 間隔で両岸に設置し，水面形の時間変化を詳 細に観測できるようにした.

太田川では，樹木管理の一環として平成15年に詳細な 樹木調査が行われている. 調查範囲内の樹木に関して, 平面座標および樹種・密度・樹高・胸高直径・枝下高を 観測し, 平成17年9月洪水前の樹木データを記録した. このため, 洪水前後の樹木の状況を比較することにより， 洪水で倒伏・流失した樹木の位置や面積等を把握できる. 図-3, 図-4, 図-5及び表-1は砂州上の樹林化が顕著であ った区間の調査結果を示す。赤いプロットが樹木の繁茂 位置を示し, 調査結果の胸高直径, 樹高, 枝下高は各領 域の樹木の平均值を示している.

\section{(2) 河道内樹木の繁茂形態}

平均河床勾配は9.4km付近を境として変化している. 8.0-9.4kmの区間の河床勾配は1/1040，9.4-13.0kmの区間は 


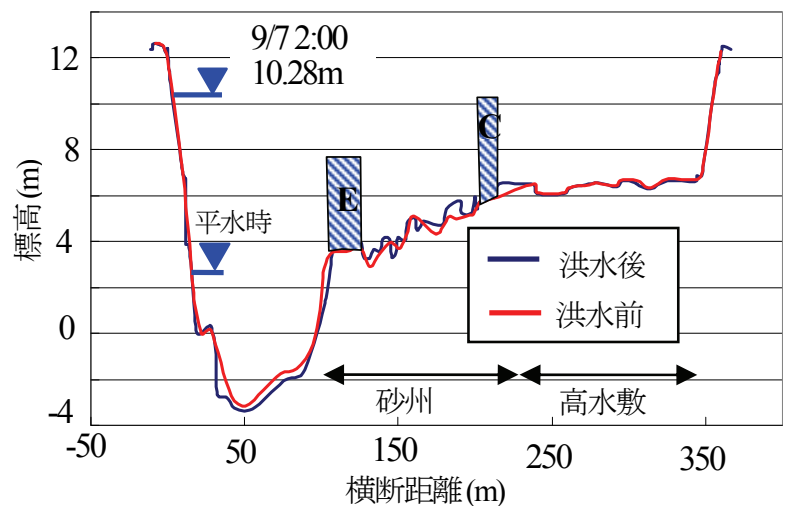

(a) 太田川 $9.2 \mathrm{~km}$

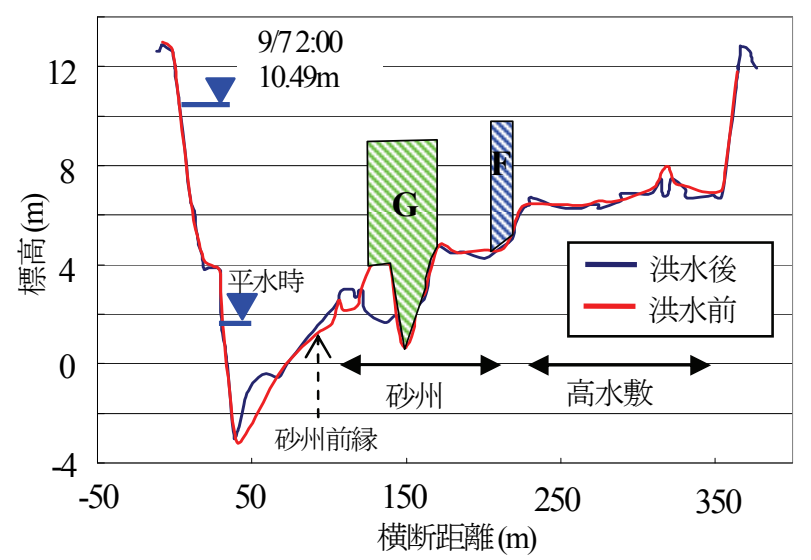

(b) 太田川 $9.4 \mathrm{~km}$

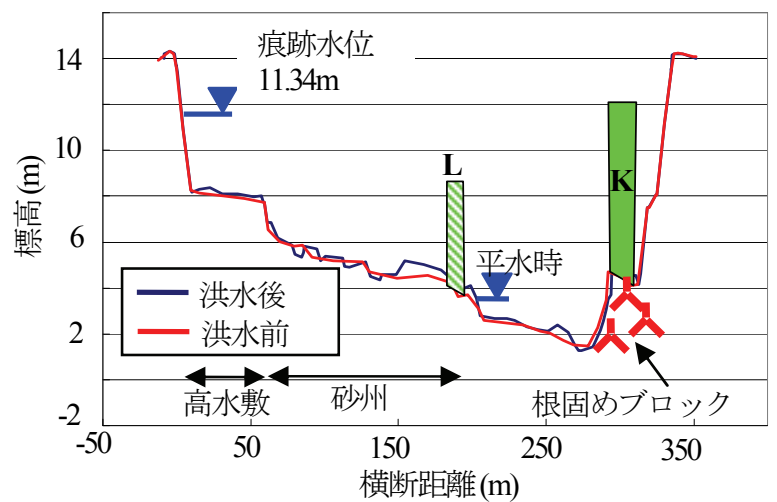

(c) 太田川 $10.6 \mathrm{~km}$

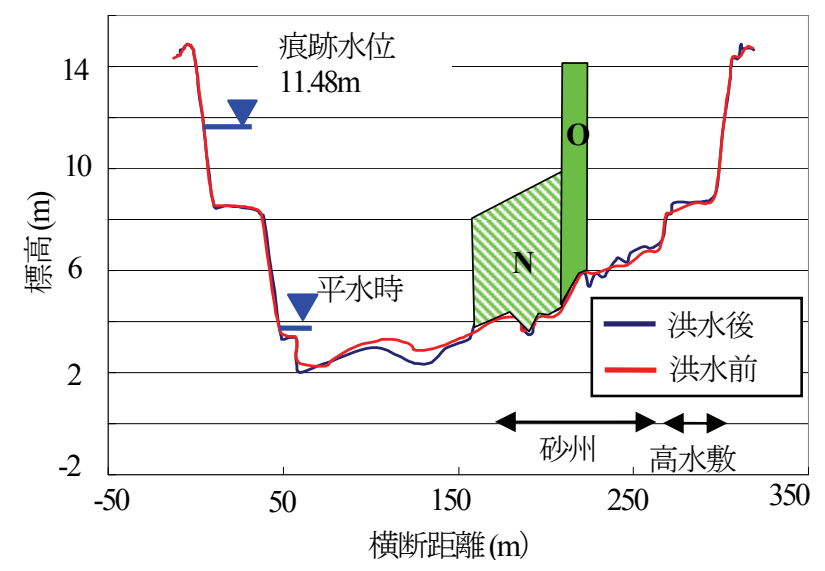

(d) 太田川 $11.0 \mathrm{~km}$

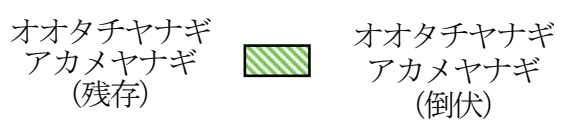

オオタチヤナギ アカメヤナギ (残存)

オオタチヤナギ
アカメヤナギ (倒伏)

図-6 横断図と樹木繁茂位置

1/800である．図-6に横断図と樹木繁茂位置を示す．樹木 の繁茂位置は，平成15年の調査結果を用いた．河床勾配 が緩くなる9.4kmより下流では，図-6(a)(b)に示すように 澪筋河床と砂州高との比高差が大きく, 砂州は砂礫で構 成されている．河床勾配が急な $9.4 \mathrm{~km}$ より上流では，図6(c)(d)に示寸ように相対的に澪筋河床と砂州高との比高 差が小さく, 砂州は粗㗜・粗石を中心とする粗い河床材 料で構成されている. 対象区間の上流(13.6km付近)には 可動堰である高瀬堰が設置されている．堰下流（13.4 12.6km付近）では中州の樹林化が顕著である.

本節では，河道特性と樹木の繁茂形態の関係について 示す. $9.4 \mathrm{~km}$ 付近は図-3に示すように河道が大きく湾曲 しており，その内岸側には大規模な砂州が形成されてい る. 図-6(a)は9.2km, 図-6 (b)は9.4kmにおける横断図, 表-1 (A〜G) は樹木繁茂状況を示寸.この付近の砂州の 樹林化は平成2年頃から始まり，平成15年の調査では砂 州の前縁に樹木が密生し，樹木群 $\mathrm{B} \cdot \mathrm{E}$ は樹木密度が 0.2 $\left(\right.$ 本 $\left./ \mathrm{m}^{2}\right)$ を上回っている. マグワ（樹木群A·B・C・D・E・ F）は低水路との比高差のある安定した砂州上に繁茂し ている.アカメヤナギ・オオタチヤナギといったヤナギ

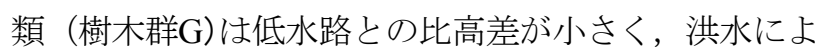

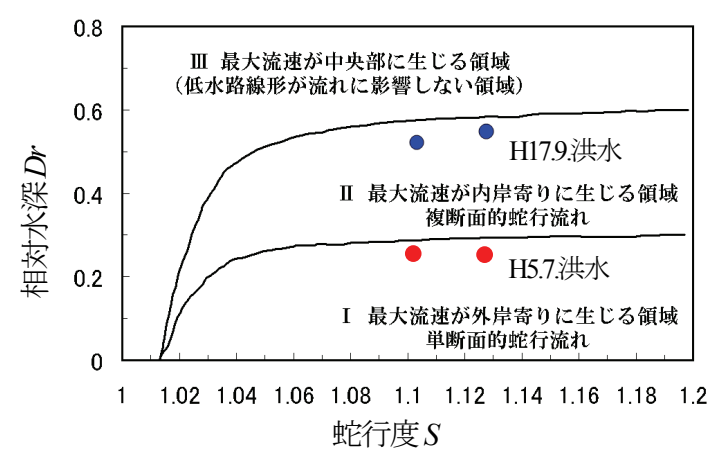

図-7 相対水深と蛇行度の関係1)2021)

る擋乱を受けやすい砂州上に繁茂している．9.4km付近 と同様の傾向が太田川の下流域で見られる．図-4は $10.2 \mathrm{~km} \sim 10.6 \mathrm{~km}$ 付近の樹木の繁茂状況を示す．図一6(c)は 10.6kmにおける横断図, 表-1(H〜 L)は樹木繁茂状況を示 す。この地点も平成2年頃から樹木の繁茂が確認でき， 平成15年の調査では左岸側に形成された内岸砂州上の水 際にアカメヤナギが繁茂し，低水路河床高との比高差が ある砂州上にマグワが繁茂している. 10.6km付近外岸側 の水際部に根固めブロックが施工され，それらが安定し て存在している，それらのブロック間には樹高・胸高直 


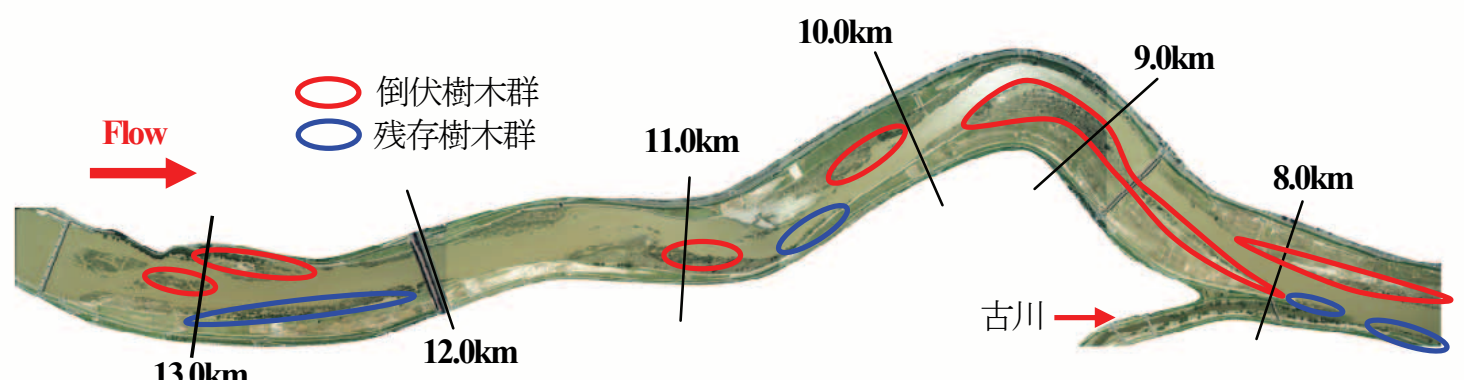

図-8 樹木の倒伏・残存位置（平成 17 年 9 月洪水発生直後に撮影)

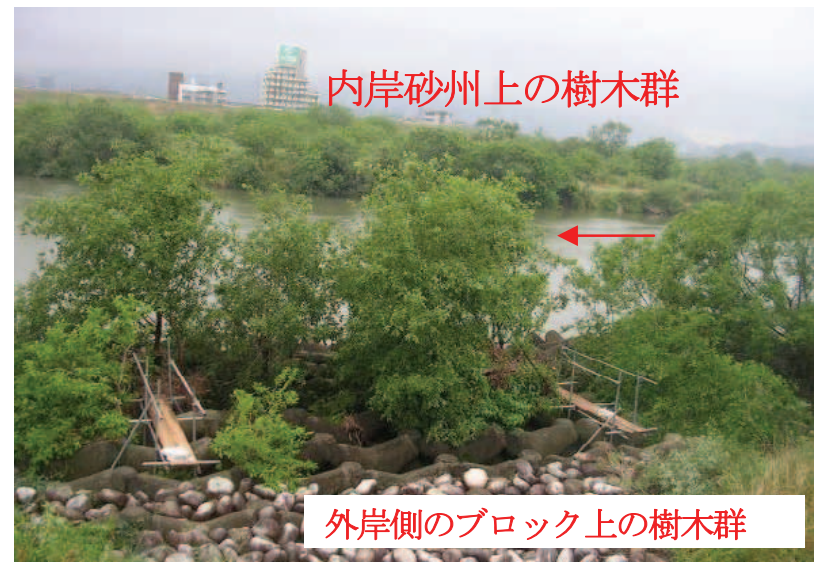

写真-1(a) $9.2 \mathrm{~km}$ 付近洪水前

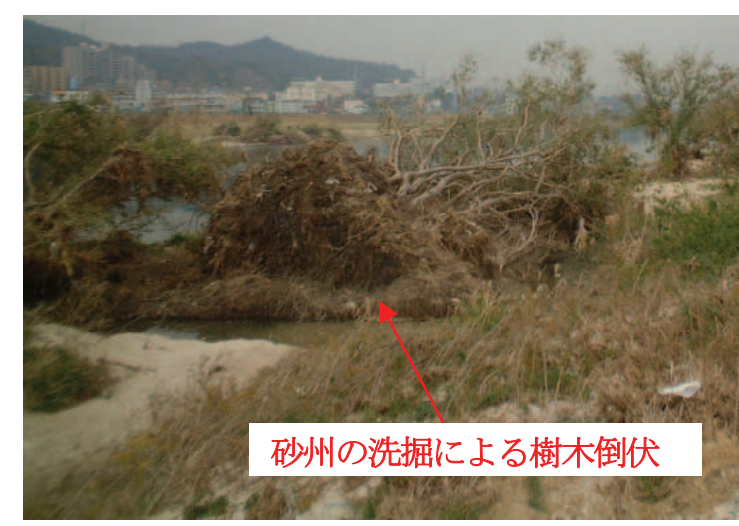

写真-2 $8.8 \mathrm{~km}$ 付近樹木倒伏状況

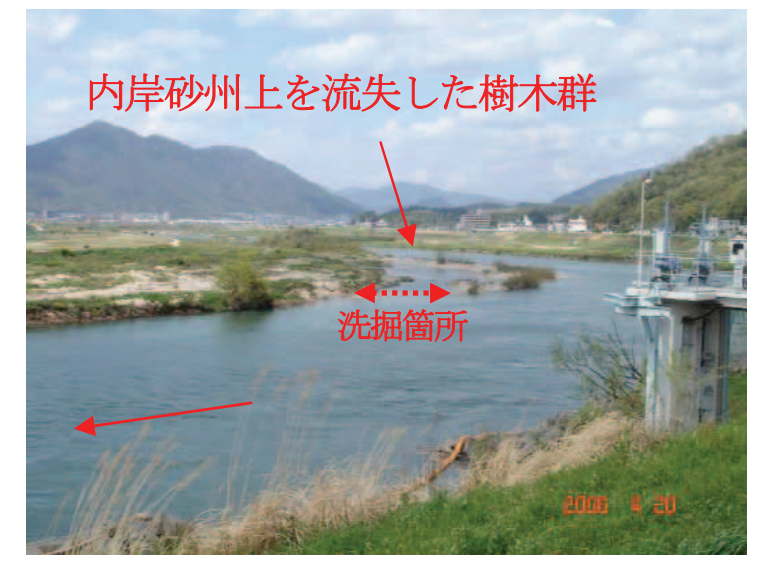

写真-1 (b) $9.2 \mathrm{~km}$ 付近洪水後

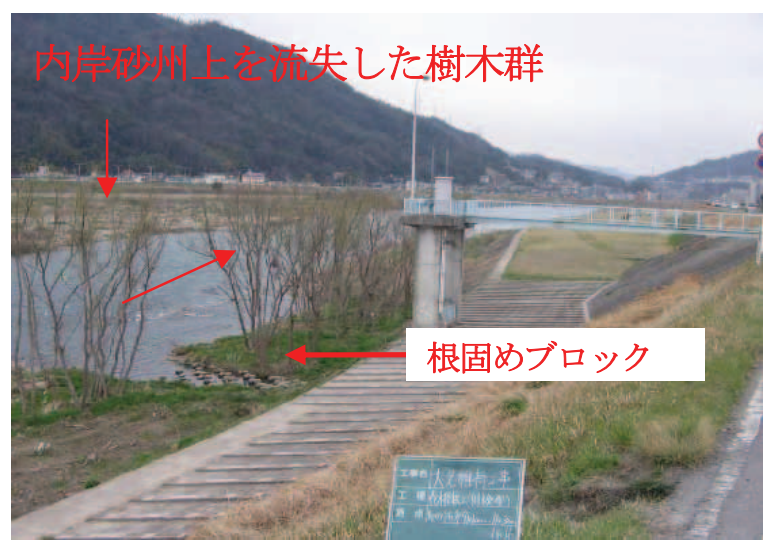

写真-3 $10.8 \mathrm{~km}$ 付近樹木残存状況 径の大きいアカメヤナギが繁茂している．図-5は11.0km 付近の平面図, 図-6(d)は11.0kmにおける横断図, 表-1(M 〜P)は樹木繁茂状況を示す. 樹木群N周辺にはワンドが 形成されており，この付近にアカメヤナギが密生してい る. 樹木群Nは平成 8 年頃から存在し, 平均枝下高が $0.1 \mathrm{~m}$ ，平均樹高が $6.3 \mathrm{~m}$ の樹冠部の面積が大きい低木であ る. 樹木群Oは平成 2 年頃から存在し, 平均枝下高 $3.3 \mathrm{~m}$, 平均樹高 $10.7 \mathrm{~m} の$ 高木である.

\section{3. 樹木の倒伏機構}

\section{(1)平成17年9月洪水による樹木倒伏}

平成17年9月太田川洪水は, 計画高水位に匹敵するよ うな大洪水であった（図-2）。検討対象区間における2 つの蛇行部（蛇行中心 $9.4 \mathrm{~km} \cdot 10.6 \mathrm{~km}$ ) の蛇行度 $S$ (低水 路蛇行長／低水路蛇行波長）はそれぞれ1.10と1.13であ る. 平成17年9月洪水における水位ピーク付近の相対水 深 $D r$ （高水敷水深／低水路水深）は約 0.5 程度であった. 岡田・福岡らによる相対水深 $D r$ と蛇行度 $S$ の関係に上記 の数值をプロット寸ると図-7のようになる1220,21).これよ 


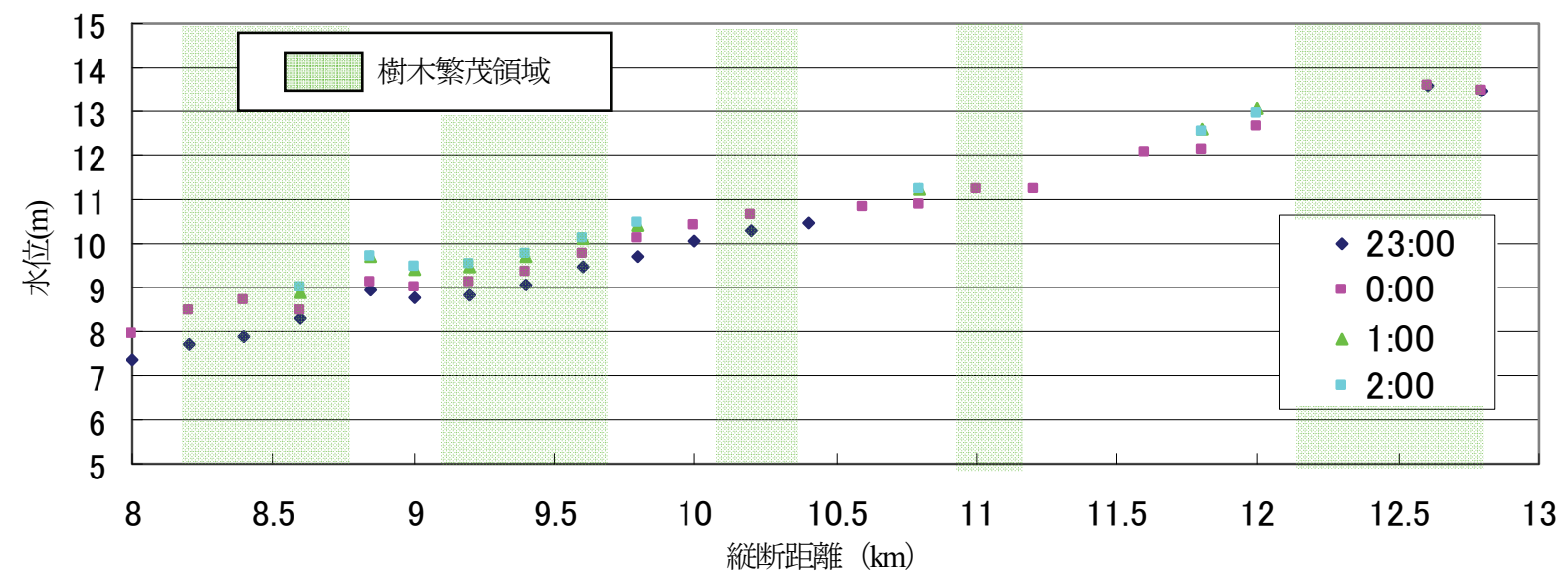

図-9 水位上昇期における観測水面形（左岸）

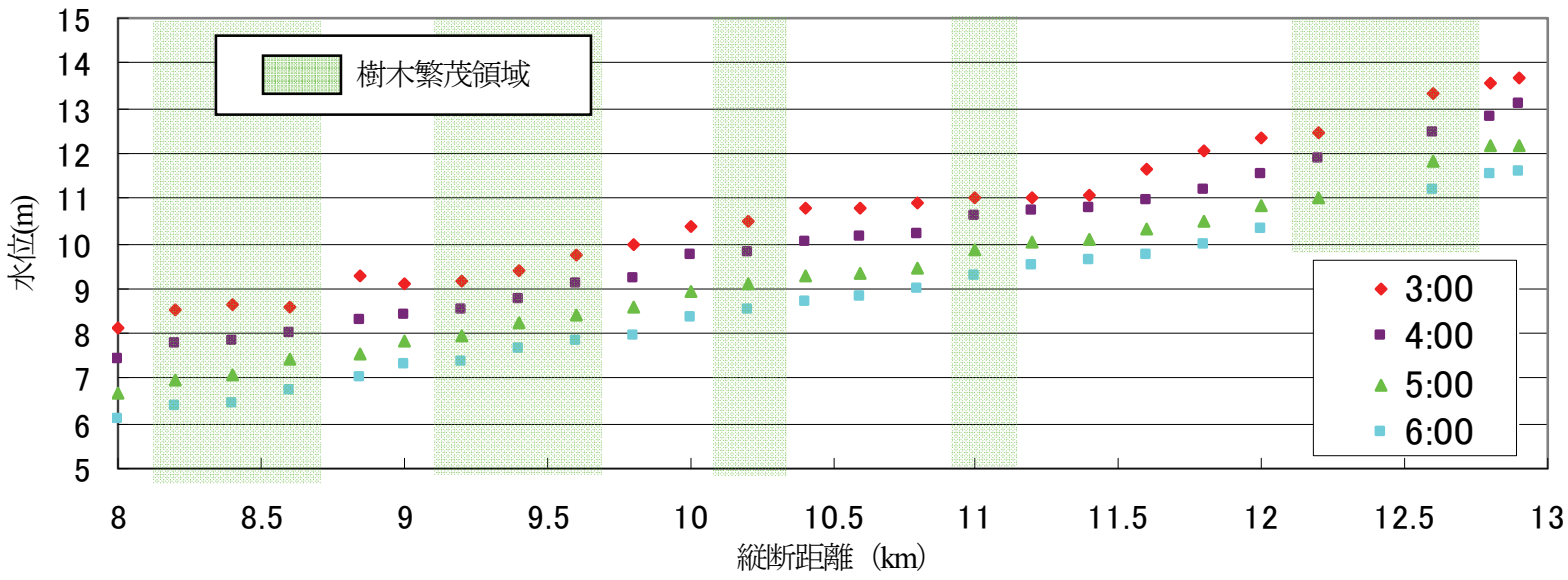

図-10 水位下降期における観測水面形（左岸）

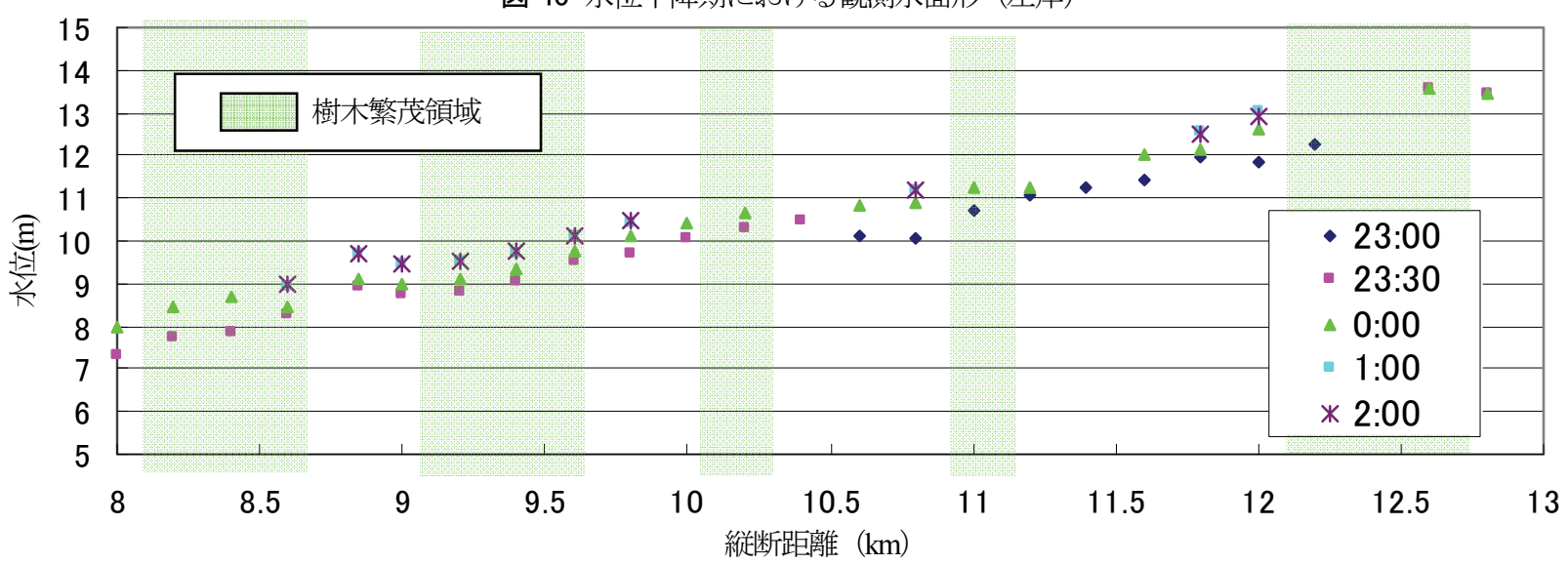

図-11 水位上昇期における観測水面形（右岸）

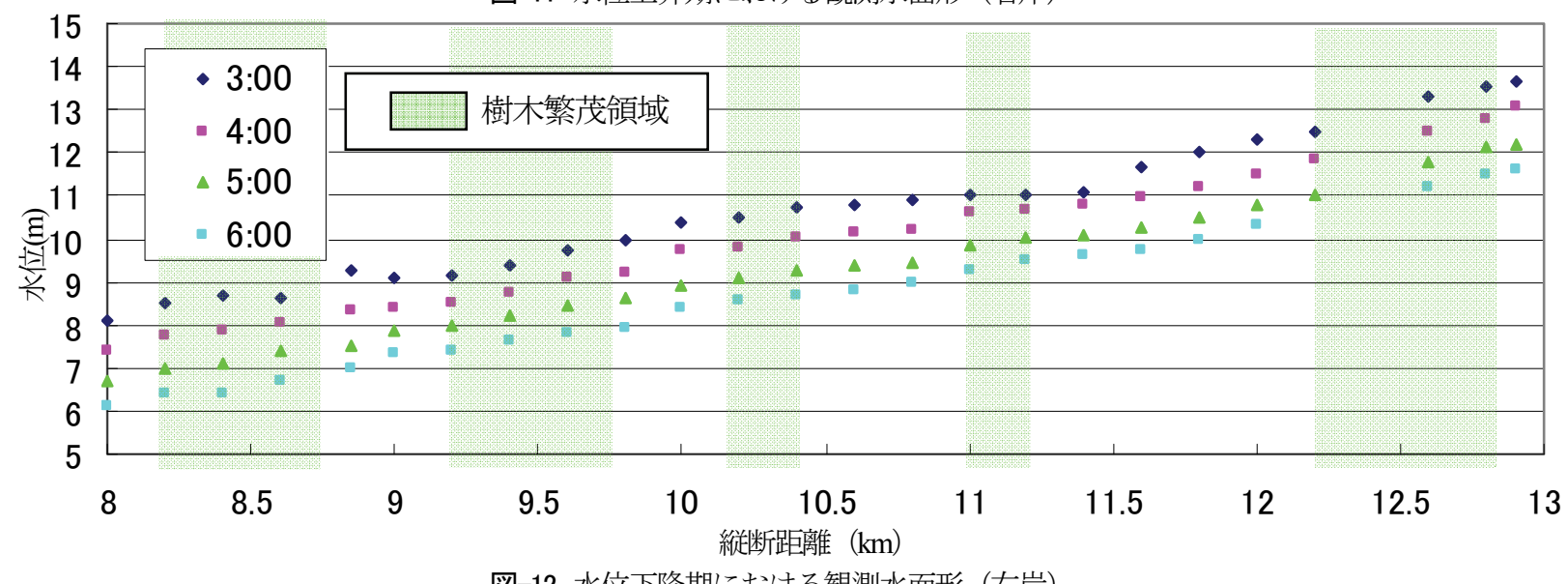

図-12 水位下降期における観測水面形（右岸） 


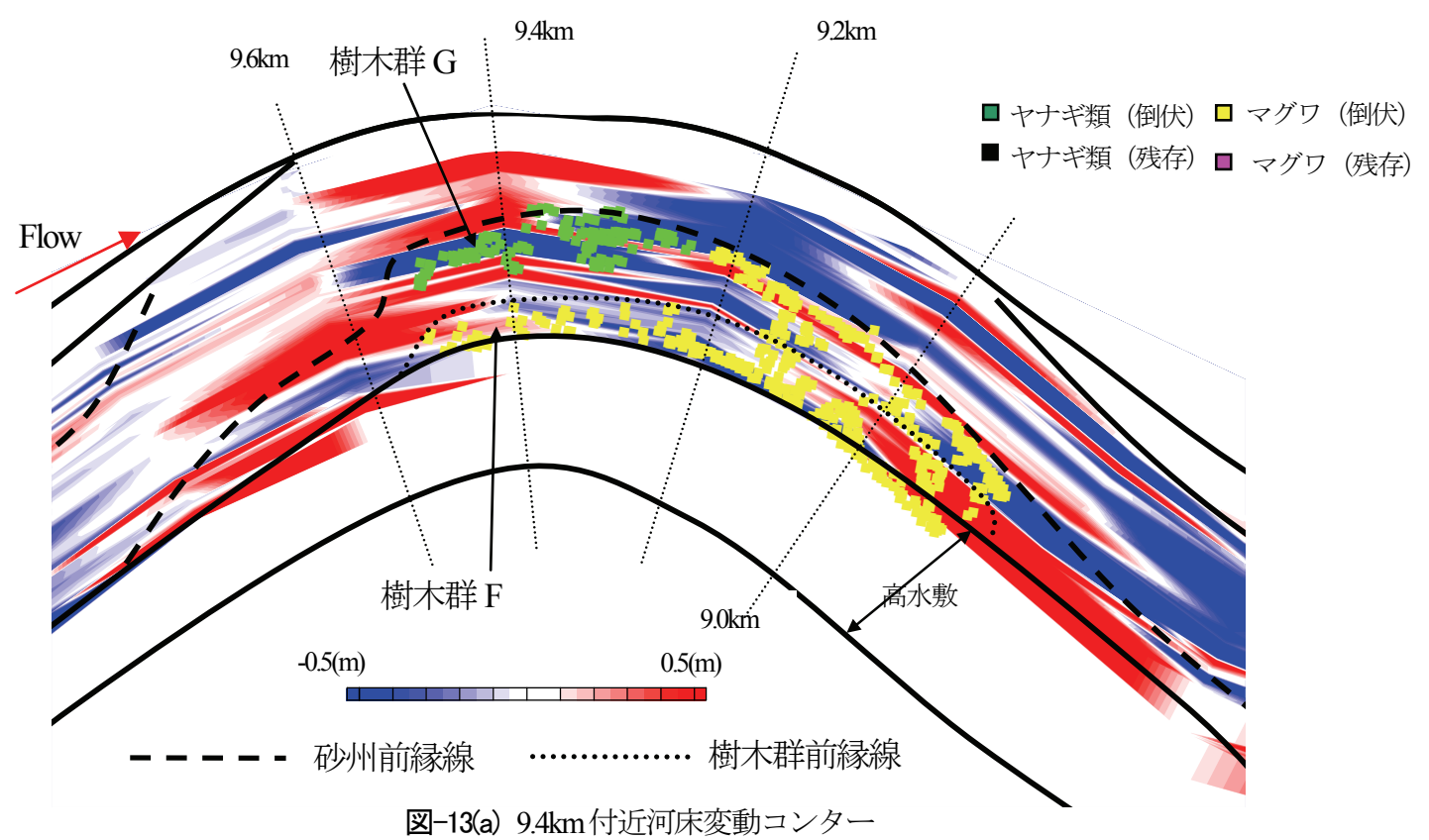

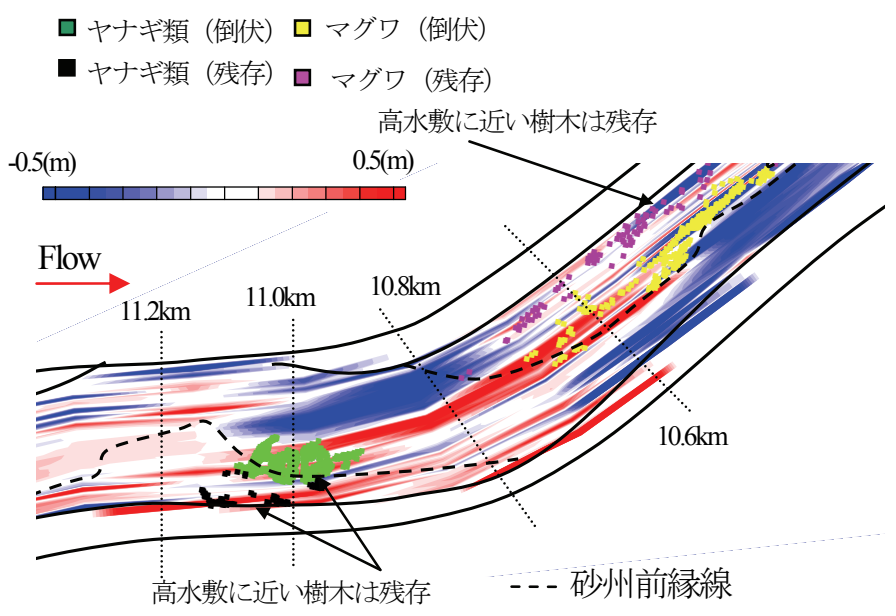

図-13(b) $11.0 \mathrm{~km}$ 付近河床変動コンター

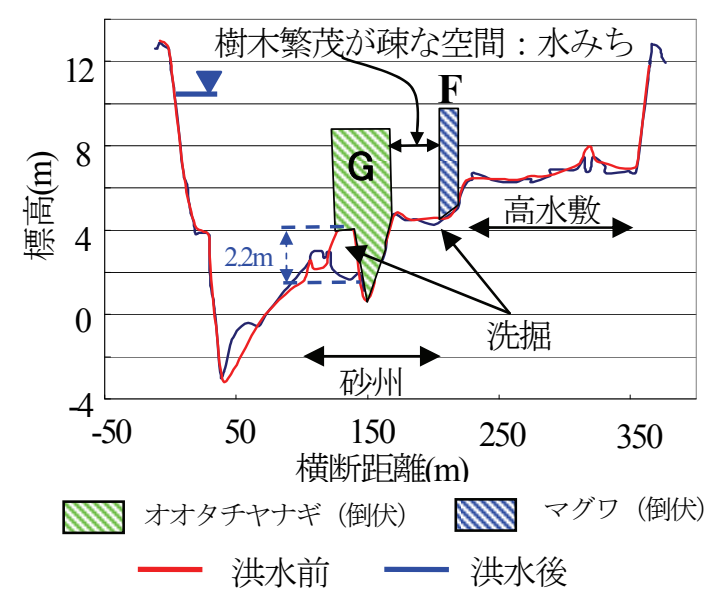

図-149.4km横断図と水みちの位置
り洪水は，水位ピーク時に内岸寄りを主流が走る複断面 的蛇行流れを呈していたと考えられる. 図-8は平成17年 9月洪水直後の航空写真であり, その上に樹木の倒伏・ 流失した箇所と樹木が残存した箇所を示す。写真-1(a), 写真-1 (b) は洪水前後の9.2km付近の内岸砂州の状況を示 す. 平成17年9月洪水は内岸寄りを主流が走ることによ り，水位ピーク付近において内岸砂州上に繁茂していた 樹木群には激しい力を及ぼし，このため内岸砂州上の樹 木群は，写真-1(b)，写真-2に示寸ように樹木の周辺の河 床が大きな洗掘を受け，根こそぎ倒伏した．一方，外岸 側に位置する樹木群のほとんどは樹木が残存した．外岸 側には写真-3に示すように外岸の洗掘防止のために根固 めブロックが施工されている. ブロックで覆われている 外岸沿いに生育している樹木群は，ブロックが河床洗掘 を抑えているために，外岸の大きな流速に対しても流失 することなく残存している，従って，樹木が繁茂してい
る位置の河床の洗掘の程度が樹木倒伏に影響したものと 考えられる.

\section{(2) 洪水観測水面形の時間変化}

観測された水面形の時間変化には，河道の形状や樹 木繁茂等の河道特性の影響が現れる ${ }^{1), 6}$. 平成17年9月洪 水の水面形の時間変化には，樹木倒伏の影響が現れてい ると考えられる. 図-9は水位上昇期における左岸側の観 測水面形，図-10は水位下降期における左岸側の観測水 面形を示寸．図-11, 図-12は同様に右岸側の水面形を示 す. 水面形は，200m間隔に設置された簡易量水標と自 記水位計により観測されたもので，ここでは，9月6日 23:00 7日6:00の水位データを用いている. 水位観測の間 隔を $200 \mathrm{~m}$ に選んだ理由は，樹木群の倒伏状況を水面形 から判断できるようにするためである。平成17年9月洪 水は計画高水位に達する洪水であったため, 水位が簡易 
量水標の設置高さを越えた箇所があった. このため, 数 箇所で水位ピーク付近のデータが久損している. 図-9, 図-10を比較すると，水位上昇期と水位下降期では水面 形が大きく異なる．水位上昇期の水面形は，樹木の繁茂 している領域の上流では樹木群の存在により水位が堰上 げられ，水面形が緩やかになり,樹木群の区間で水面形 が急になり, 全体として縦断的な変化が大きい. 一方, 水位下降期における水面形は全体として滑らかになって いる. これは，水位上昇期では樹木の影響が水面形に現 れているが，水位下降期では多くの樹木が倒伏または倒 伏に近い状態にあるためと考えられる.

\section{(3) 内岸砂州の洗掘と樹木倒伏}

図-13(a), 図-13(b)は洪水前後に測定された横断測量結 果を用いて描いた河床変動コンター上に平成 17 年 9 月 洪水後における樹木の残存・倒伏状況を示寸. 破線は, 砂州の前縁線，樹木群の前縁線を示寸．図-14 は 9.4km における横断図と樹木群の残存・倒伏状況を示寸．最大 洗掘は内岸砂州の前縁付近で生じており, $9.4 \mathrm{~km}$ 地点で は約 $2 \mathrm{~m}$ もの洗掘を受けている. この内岸砂州の前縁の 洗掘は縦断的に生じており, これは洪水ピーク時に洪水 流の主流が内岸寄りを走る複断面的蛇行流れを呈してい たためであると考えられる 20211. 砂州の前縁には洪水前 に樹木群 $\mathrm{G}$ （オオタチヤナギの群落）が存在しており， これらの樹木は内岸砂州前縁の洗掘によって倒伏したも のと考えられる.ささらは，洗掘深が大きかったことか ら樹木群の一部は流失したものと考えられる. 高水敷寄 りに位置し，比高差が高い内岸砂州上に繁茂している樹 木群 $\mathrm{F}$ （マグワの群落）の前縁も $30(\mathrm{~cm})$ 程度の洗掘を受 けており,この樹木群前縁の洗掘は縦断的に生じている. これは，樹木群 $\mathrm{G}$ と樹木群 $\mathrm{F}$ の間には樹木が疎に生え た空間が存在しており，この空間を内岸砂州に乗り上げ た主流が水みちとして走ったことにより，内岸砂州前縁 付近の樹木群 $\mathrm{G}$ だけでなく樹木群 $\mathrm{F}$ の前縁の河床洗掘 を生じさせたものと考えられる.このように砂州前縁や 樹木群前縁で生じた河床洗掘が引き金となり，樹木群 $\mathrm{G}$, Fが倒伏したものと考えられる.

図-13(b)には11.0km付近における洪水前後の河床変動 コンターが示されている。この地点は洪水前にアカメヤ ナギが密生していた地点である. 比高差のある砂州上に は樹高約11(m)程度（平成15年調査時）の比較的高木の アカメヤナギ（樹木群O）が繁茂し，比高差の小さい砂 州の前縁付近には比較的低木のアカメヤナギ(樹木群N) が繁茂していた。 図-13(b)より砂州の前縁で洗掘を受け, 樹木の倒伏が顕著であった。一方，比高差のある高水敷 寄りの砂州上では顕著な洗掘が生じておらず，樹木は残 存する傾向にあった. 洪水前後の横断測量結果と樹木倒 伏位置との関係及び写真-3に示したように10.6kmの右岸
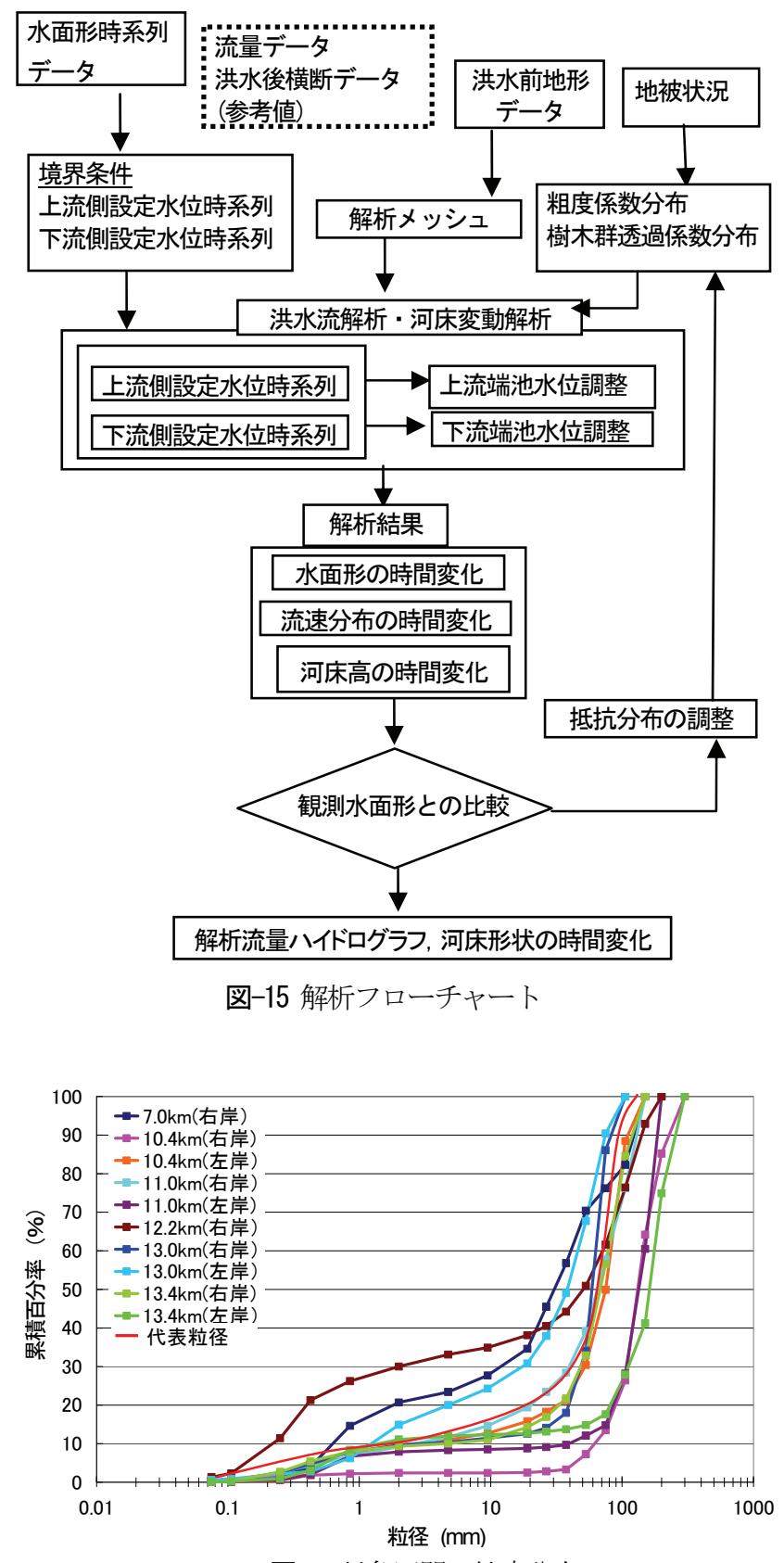

図-16 対象区間の粒度分布

側の高速流発生区間でもブロックが移動しなかったため, 樹木が残存していることからも，太田川での洪水流によ る樹木倒伏の主な要因は砂州河床の洗掘であることが明 らとなった。

\section{4. 非定常二次元洪水流 · 河床変動解析}

\section{(1) 解析方法}

これまでの一般的な河床変動解析は, 洪水ピーク時に 付いた洪水痕跡水位の緹断分布とピーク流量を用いて解 析を行い, 洪水後に観測された河床形状と解析結果の比 較検証を行っており，洪水中の時々刻々の河床高の変化 については解明が困難であるとして，多くの場合検討の 
対象外におかれてきた。しかし，洪水中に生じている 河床変動の時間変化を知ることは河川管理上重要である。 福岡は洪水中の河床変動を求めるためには, 洪水流の水 面形の変化を時々刻々取り入れた非定常二次元洪水流・ 河床変動解析法の必要性を強調している2223).これは, 水面形の時間変化には洪水中の河床変動の影響が現れて いるため ${ }^{1,0,9}$ ，洪水流と河床変動解析を水面形の時間変化 の観測值に追随するように一体的に行うことにより，実 際に起きた洪水の洪水中の河床変動を知ることが可能で あるという考えに基づいている.この方法は，鈴木・福 岡らによる利根川下流域を対象とした研究 24 , 長田・福 岡による常願川での一次元, 二次元河床変動解析 ${ }^{252920}$ で 実行され，考え方の有効性が示されている. 実験水路で は川口・藤堂らにより，同様に非定常流れにおける交互 砂州の変形・形状について検討されている277.

著者らは，太田川洪水で生じた樹木倒伏について，洪 水中の流れと河床変動の視点から検討している ${ }^{28)}$. そこ では洪水流の水面形の解析結果と観測結果の比較が中心 で, 河床変動については, 解析結果が実測值を必ずしも 十分に再現できていなかった. 本研究で河床変動解析法 の課題を改善し, 樹木群の倒伏・流失機構を検討してい る. 以下に, 改善点を示す. まず, 河床変動の解析結果 と観測結果の比較検証から, 先の解析 ${ }^{28)}$ では, 再現でき ていなかった主に以下の2点の改善を図った. 第一に,

$8.0 \mathrm{~km}$ 付近の低水路で生じた洗掘について, 解析区間を 下流側に延長して検討した．第二に，9.4km湾曲部では 樹木流失を考慮した解析を行い, 河床洗掘深について検 討した.

洪水流解析の基本式は，樹木群を考慮した非定常平面 二次元解析の式であるので，ここでは，摩擦抵抗と樹木 群抵抗の式(1)のみを示す5,9,7,7,8).河床変動については慣 用的に用いられている二次元河床変動解析法の基礎式を 用いた．解析のフローチャートを図-15に示す.

$$
\left(\tau_{0 \xi}, \tau_{0 \eta}\right)=\left(\frac{g n^{2}}{h^{1 / 3}}+\frac{g h_{\text {tree }}}{K^{2}}\right) \sqrt{u^{2}+v^{2}}(\widetilde{U}, \widetilde{V})
$$

ここで, $\left(\tau_{0 \xi}, \tau_{0 \eta}\right)$ : 反変 $\xi, \eta$ 方向せん断力, $h_{\text {tree }}$ : 樹高, $K$ : 樹木群透過係数, $n$ : 粗度係数, $h$ : 水深, $g$ : 重 力加速度, $(\widetilde{U}, \widetilde{V}):$ 反変 $\xi, \eta$ 方向流速, $(u, v): x, y$ 方 向流速である.

前述のように，樹木が大規模に倒伏し，樹木の抵抗力 が変化したため観測された水面形の時間変化には，樹木 倒伏の影響が現れている。このため, 樹木倒伏はピーク 水位を過ぎた時点で生じたものと想定される. そこで, 樹木群の抵抗力を評価する樹木群透過係数 $K$ は, 水位下 降期において水位上昇期に比べ大きな值を用い（表-2参 照）, 水位下降期の樹木群の抵抗を水位上昇期より小さ く評価することにより，水面形時間変化の解析結果が観
測水面形の時間変化を説明できるかどうか検証する．樹 木群透過係数は樹木群の繁茂状況により, 特徵的な区間 ごとにブロック分けして与え，観測された水面形の時間 変化を再現するように值を決定した．これは水面形の形 成は個々の樹木の抵抗よりも，ある区間の樹木群の平均 的な抵抗によるという考え方に基づいたものである ${ }^{8} .3$ 章で述べた通り $9.4 \mathrm{~km}$ 付近の内岸砂州には水みちとなる 場所が存在し, それが内岸砂州の洗掘と樹木倒伏が密接 に関係していることから，9.6km 9.2km間に20mの幅で樹 木群が無い（樹木群透過係数の值が無限大）領域を設け, 水みちを考慮している. 水みちの幅・長さは洪水前の樹 木繁茂状況と洪水前後の河床変動コンターから決定した. 水みちを含む区間の樹木群透過係数には，水みちでの流 速増大による樹木群内の流れとの混合による流れの付加 抵抗を考慮した值 $(K=30)$ を設定した．水位下降期に は, 洪水後の砂州の洗掘深が大きかったことから, 水位 ピーク付近で樹木群が流失したとし, 水みちでの樹木群 透過係数を無限大として解析を行う. その他の区間は, これまでの解析と同様な考えに基づき平均的な樹木群透 過係数を与えている. マニングの粗度係数は河道の断面 形, 河床材料や河床形状から判断して妥当とされる值を 用い, 樹木群とは無関係な河道固有の值としている8

河床変動の基礎方程式は流砂の連続式, 粒径別連続式 (平野の式 ${ }^{29}$ を芦田・江頭・劉 ${ }^{30}$ ) が二次元に拡張した 式）を用いた。 平衡流砂量式として芦田・道上 ${ }^{29}$ によ る粒径別平衡流砂量式を用い, 河道形状の影響は福岡 山坂の式 ${ }^{1)}$ 用いて評価している. 粒径別の限界掃流力 は, 芦田・道上 ${ }^{29}$ によって修正された Egiazaroff の式を 用い, 限界掃流力は岩垣の式 ${ }^{29}$ を用いた。 また, 交換層 の厚さには $D_{90}$ 程度の值を用いた. 対象区間の河床材料 分布を図-16 に示す. 河床材料は主に $D_{60}$ が $6(\mathrm{~cm})$ 程度の 粗碩である. 主流が乗り上げる様な場所では $D_{60}$ が 15(cm)程度の粗石となっている. 計算初期地形には洪水 前河道横断測量データを用い, 洪水後の河道横断測量デ ータを参考值として用いた。

上流端境界条件は矢口第一観測所（11.6km 左岸）に おける水位時系列データ, 下流端境界条件は $8.0 \mathrm{~km}$ 左岸 における簡易量水標により観測された水位時系列データ を用いた. 解析格子は縦断方向 297 分割, 横断方向 30 分割とした. 解析は, 左岸沿いの水面高を解とした場合 および右岸沿いの水面高を解とした場合, それぞれの水 面形について行った.

\section{(2) 解析結果}

図-17は水位上昇期における水面形の解析結果と観測 值の比較, 図-18は水位ピーク時の河床形状と初期河床 からの河床変動コンターの観測結果を示し, 水位下降期 についても同様に図-19, 図-20に示す. 図-21は洪水前後 
表-2 樹木群透過係数・粗度係数の分布

\begin{tabular}{|c|c|c|c|}
\hline \multicolumn{4}{|c|}{ 樹木群透過係数 $\mathrm{K}(\mathrm{m} / \mathrm{s})$} \\
\hline 位置 & $\begin{array}{c}10: 00 \sim 2: 00 \\
\text { (水位上昇期) }\end{array}$ & $\begin{array}{c}2: 00 \sim 3: 00 \\
\text { （水位ピーク時） }\end{array}$ & $\begin{array}{c}3: 00 \sim 7: 00 \\
\text { (水位下降期) }\end{array}$ \\
\hline $\begin{array}{c}8.0 \sim 9.6 \mathrm{~km} \text { 右岸 } \\
9.6 \sim 9.2 \mathrm{~km} \text { 右岸(水みち) } \\
10.4 \sim 10.8 \mathrm{~km} \text { 右岸 } \\
10.8 \sim 11.4 \mathrm{~km} \text { 右岸 } \\
8.0 \sim 8.8 \mathrm{~km} \text { 左岸 } \\
9.6 \sim 10.6 \mathrm{~km} \text { 左岸 }\end{array}$ & $\begin{array}{l}40 \\
30 \\
50 \\
40 \\
50 \\
50\end{array}$ & $\begin{array}{l}50 \\
40 \\
55 \\
50 \\
55 \\
55\end{array}$ & $\begin{array}{l}60 \\
\infty \\
60 \\
60 \\
60 \\
60\end{array}$ \\
\hline \multicolumn{4}{|c|}{ 粗度係数 $n\left(m^{-1 / 3} \cdot s\right)$} \\
\hline $\begin{array}{l}\text { 低水路 }(8.0-13.0 \mathrm{~km}) \\
\text { 高水敷 }(8.0-13.0 \mathrm{~km})\end{array}$ & & $\begin{array}{l}0.025 \\
0.035\end{array}$ & \\
\hline
\end{tabular}

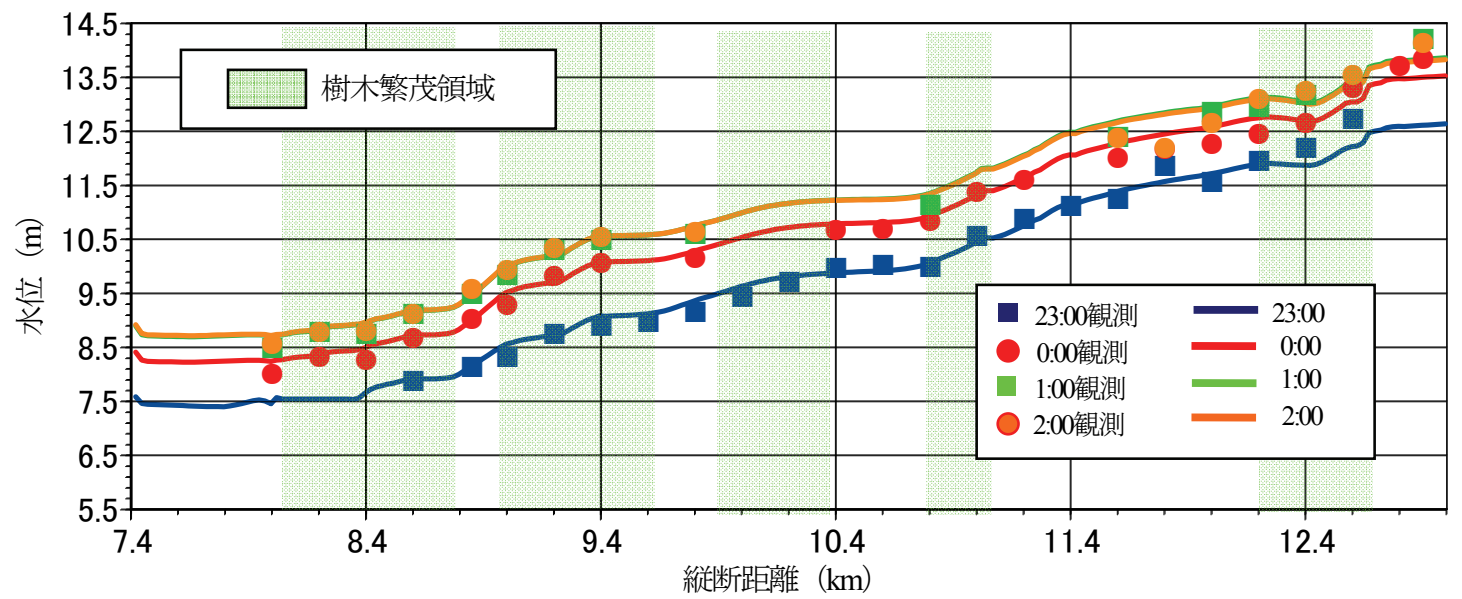

図-17 水位上昇期における水面形の解析結果と観測值の比較

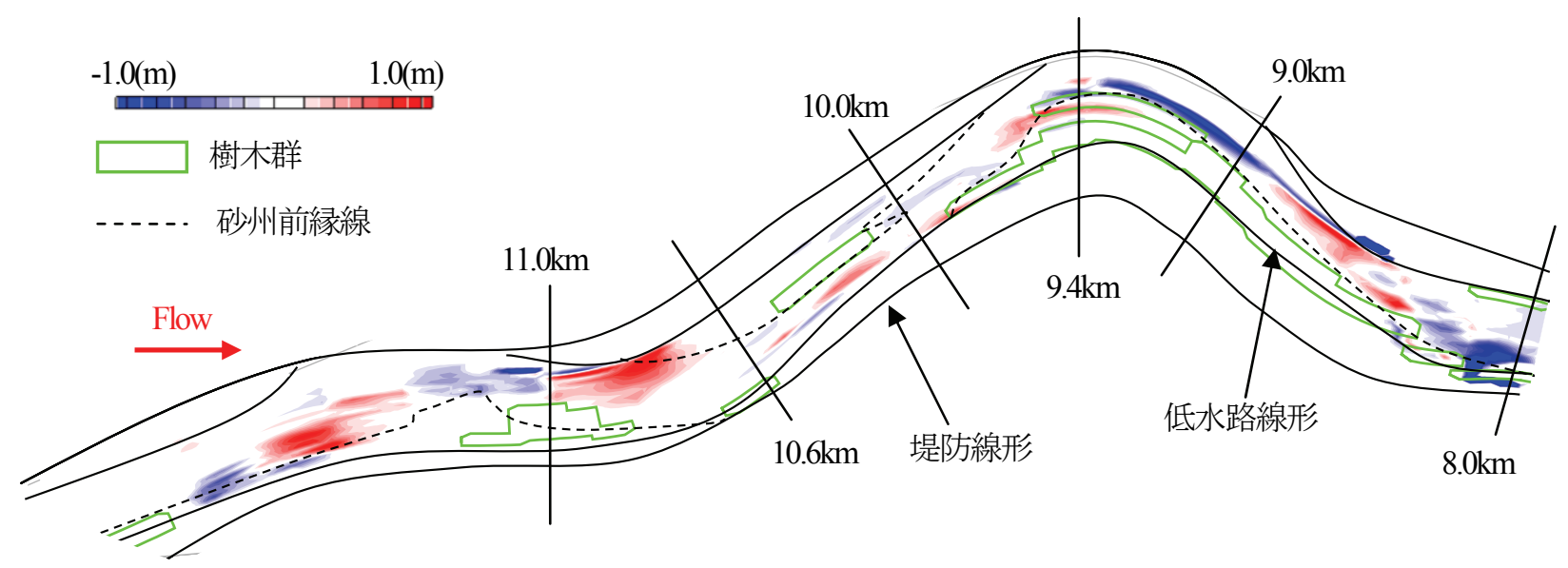

図-18 水位ピーク時(2:00)の河床と初期河床との差を表す河床変動コンター（解析結果）

に行われた横断測量結果を用いた実測河床変動量のコン ターを示す。それぞれの困の破線は，砂州の前縁線を示 す. 表-2は解析に用いた樹木群透過係数および粗度係数 を示す．水位上昇期では，水みちのある区間の樹木群に よる流れの抵抗が大きくなることから，他の区間より小 さな樹木群透過係数 $(K=30)$ を用いている. 図-17, 図一 19に示すように解析結果は， $12.0 \mathrm{~km}$ 付近で観測水面形と 解析水面形の間にやや差が生じているものの, 水位ピー ク付近で生じた樹木群の倒伏や流失を考慮し，時々刻々 の流れ場と河床変動の解析を同時に行うことで，観測水
面形の時間変化を再現している. 図-20に示す計算終了 後の河床と初期河床との差を表す河床変動コンターは, $9.4 \mathrm{~km} 8.0 \mathrm{~km}$ における樹木群のある湾曲部の砂礫砂州で 生じた砂州前縁から主流路にかけての洗掘をほぼ再現し ている. $10.0 \mathrm{~km}$ 付近も洗掘を受ける傾向にあり, これも 実測值を概ね説明している，従って，河床変動の解析結 果は，観測結果に見られるように，樹木群のある砂州の 前縁が洗掘を受ける傾向を概ね再現することができてお り，前述の課題 ${ }^{28)}$ の改善が図られていると考える. 一方, 解析結果は9.4km砂州前縁で生じた2(m)もの洗掘深の局 


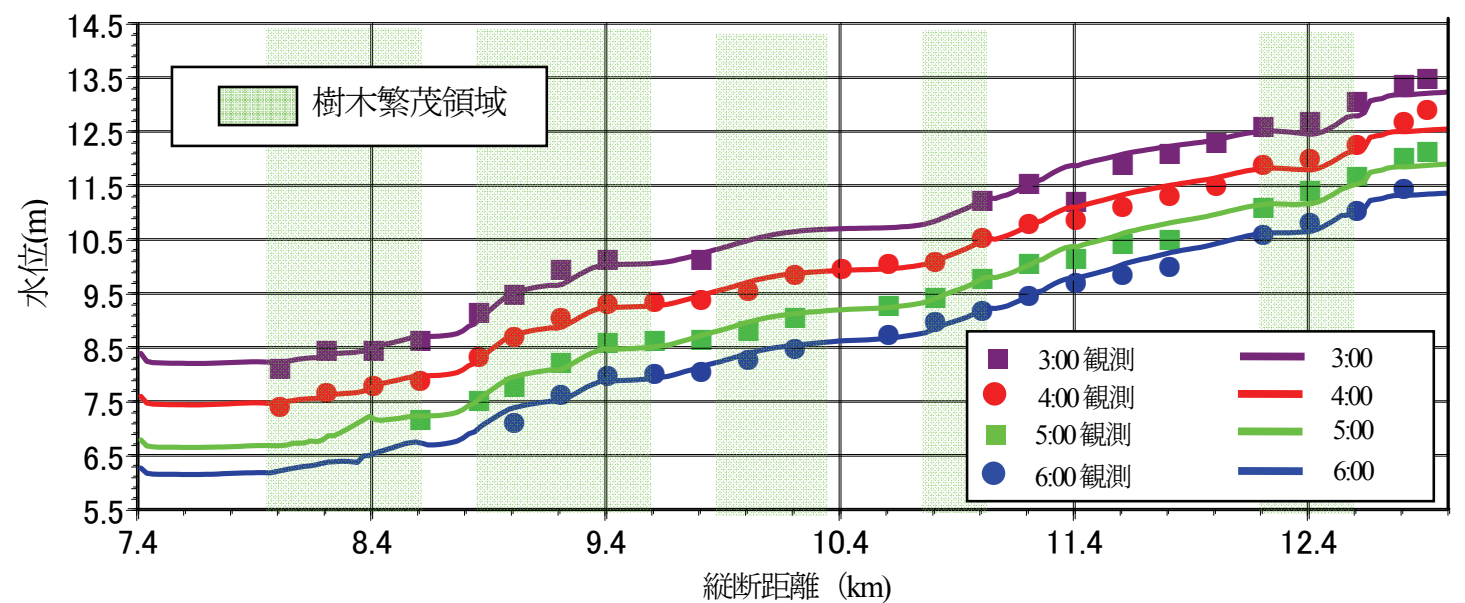

図-19 水位下降期における水面形の解析結果と観測值の比較

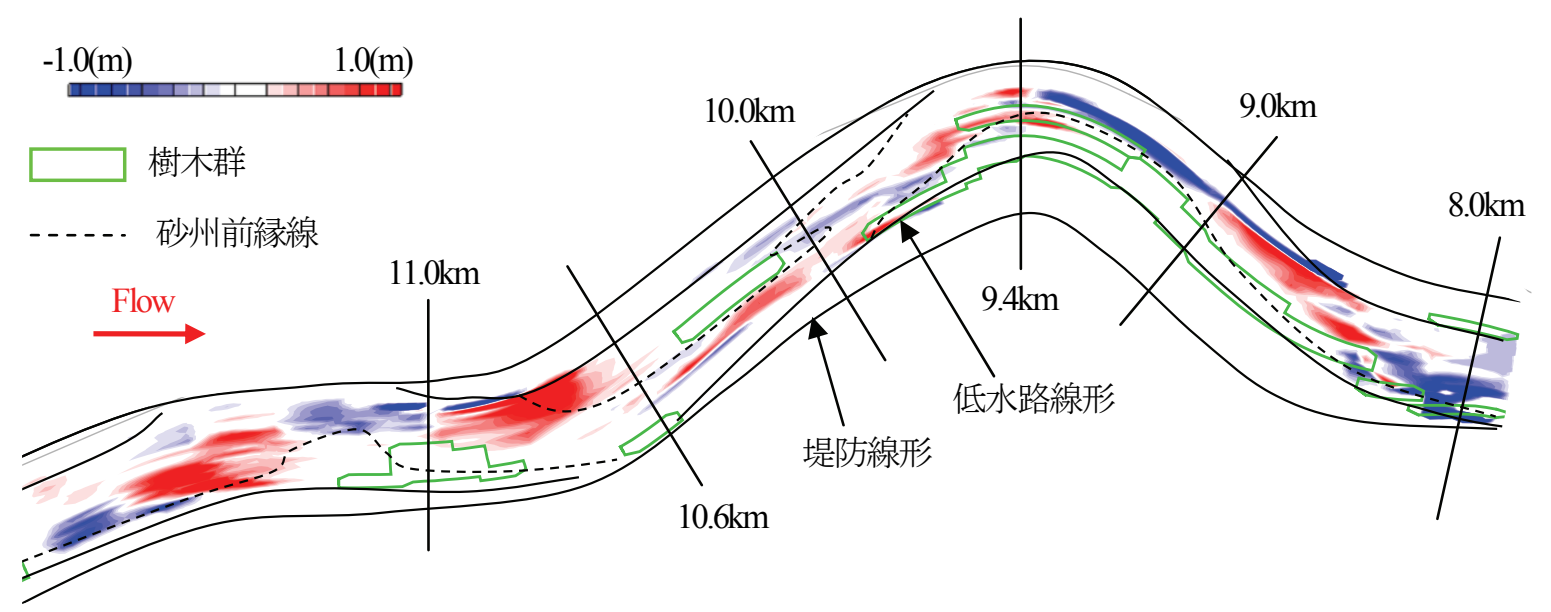

図-20 計算終了後(6:00)の河床と初期河床との差を表す河床変動コンター（解析結果）

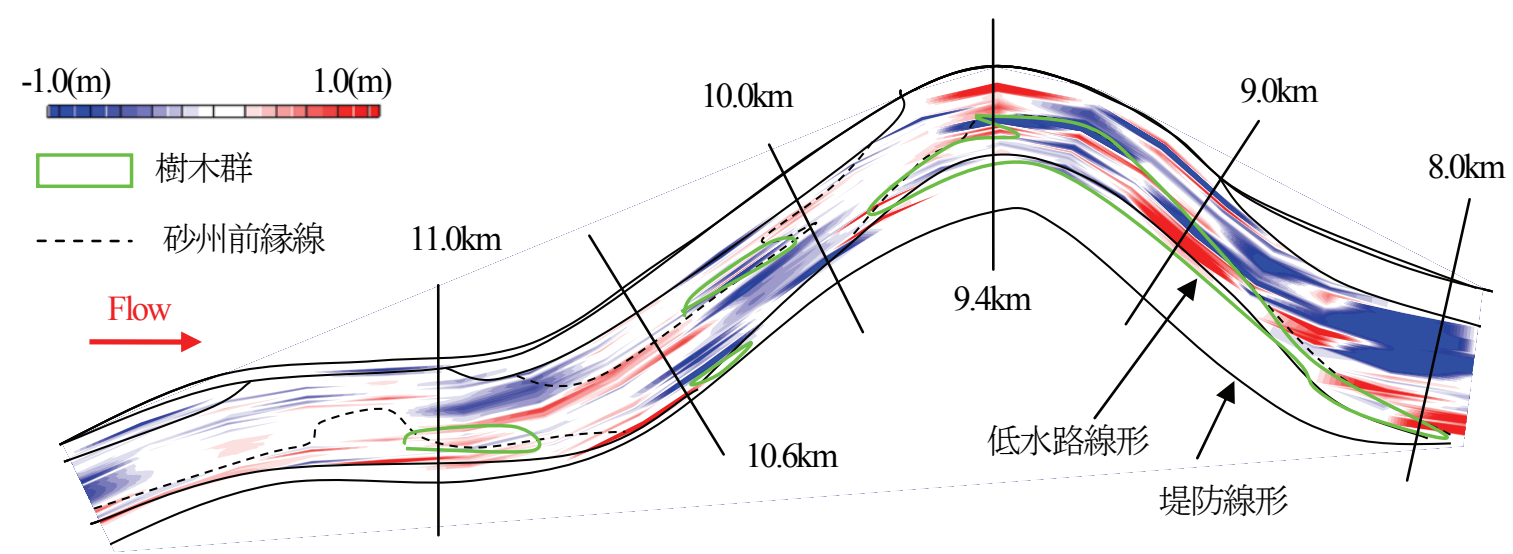

図-21＼cjkstart洪水前後の河床変動コンター（実測）

所洗掘を再現できていない. $11.0 \mathrm{~km}$ 付近では観測結果に 示したような樹木群前縁の砂州の洗掘が再現できておら ず，解析では澪筋付近が洗掘を受けている.これらの理 由は以下に示す二つが考えられる．第一に $9.4 \mathrm{~km}$ 付近の 砂州は5 7(cm)の粗磎で構成され，10(cm)以上の粗石も多 く存在する. $11.0 \mathrm{~km}$ 付近の河床は，主に粒径15(cm)を超
える粗石で構成されている（写真-4, 写真-5）. このよ うに大礫・石碟からなる河道の土砂移動は, 長田・福岡 が常願寺川の調査及び解析で示したように石礫が支配的 な非平衡性が強い特性を持ち，用いた芦田・道上式が想 定したような砂砶の移動形態というよりも，石碟が支配 的な土砂移動形態をとるものと考えられる ${ }^{25,26,31)}$. この 


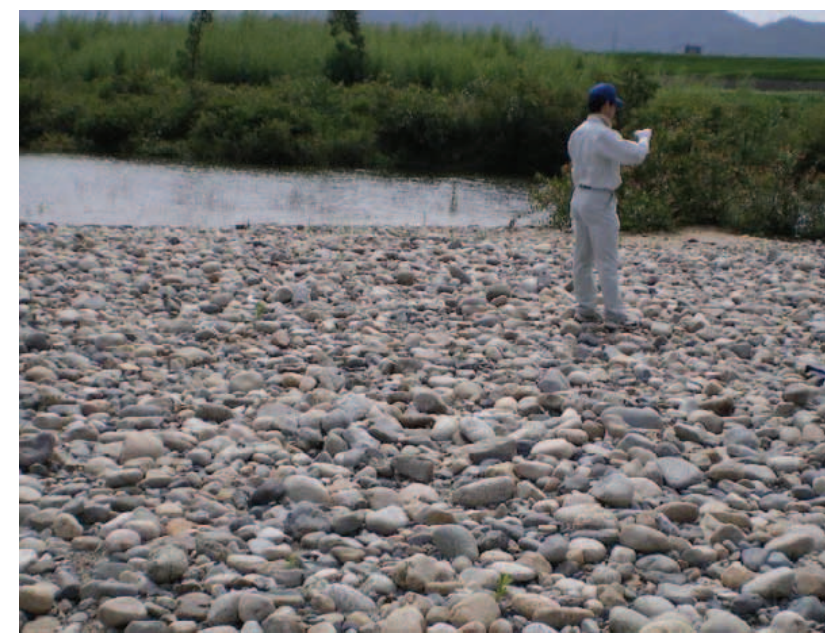

写真-4 $11.0 \mathrm{~km}$ 右岸の河床状況

ような石碩河床の土砂移動を従来の土砂輸送に基づく解 析法では適切に評価できず，このため $11.0 \mathrm{~km}$ 付近や $9.4 \mathrm{~km}$ 砂州の河床変動を十分説明できていないものと思 われる. 第二に樹木群透過係数を用いた解析は，平均的 な樹木群抵抗及び流れ場を表すもので，個々の樹木によ る局所流れや抵抗を表現するものではないことが挙げら れる．以上に示した二点は今後の課題であるが，洪水終 了後の解析結果は，石碩河道の河床変動や局所的な河床 変動の精度については十分でないものの, 砂州前縁にお ける洗掘をほぼ再現できている，従って，水面形時系列 観測值を用いた洪水中の流れと河床変動の一体的推算法 は，著者らが着目し，重点的に検討した樹木群の繁茂す る箇所の河床変動現象の再現を可能にしている.

図-22(a)(b)に洪水ピーク時（午前2:00）における流速分 布と最大流速線を示寸．実線は洪水前河床形状を示寸。 9.4km付近湾曲部では内岸砂州上の樹木群付近で最大流 速が生じ，約 $3(\mathrm{~m} / \mathrm{s})$ 以上の流速が生じている．水みち内 の流速も3(m/s)程度生じており, 洪水ピーク時には複断 面的蛇行流れをしていたことにより，内岸砂州上の水み ちにも流れが集中していたことが分かる.このため, 図-18に示すように $9.4 \mathrm{~km}-9.0 \mathrm{~km}$ 砂州の前縁が洗掘を受け ており，水位ピーク時に生じた砂州前縁の洗掘によって 樹木群の倒伏・流失が生じたことが分かる.

図-23 に矢口第一水位・流量観測所における流量八イ ドログラフの観測結果と解析結果を示す. 流量ハイドロ グラフの解析結果は，実測值を良く説明している.

このように，樹木倒伏や河床変動の影響が現れている 水面形の時間変化を追随寸るように非定常平面二次元洪 水流と河床変動を一体的に解析することにより, 観測し た洪水の洪水中に生じた河床変動を説明し，洪水流量八 イドログラフを明らかにすることが出来た. その結果, 水位下降期（午前 3:00 頃）には樹木が倒伏していたこ と, 太田川の対象河道区間に繁茂している樹木群は, 概

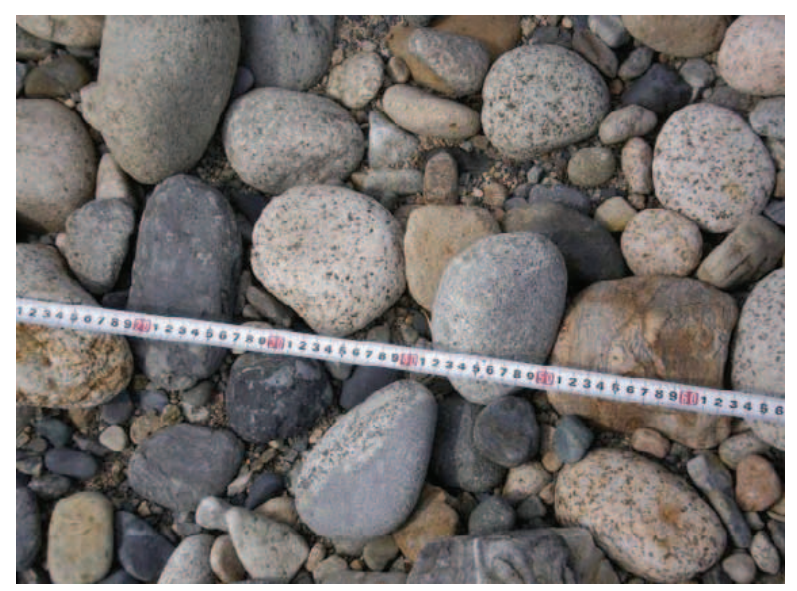

写真-5 $11.0 \mathrm{~km}$ 右岸の河床材料

ね 7,000( $\left.\mathrm{m}^{3} / \mathrm{s}\right)$ クラスの洪水流量で倒伏すること，また， 洪水後の状況から倒伏した樹木群の大部分は, 内岸砂州 上の樹木群であることが分かった。

\section{（3）樹木の倒伏モーメントを用いた検討}

洪水流による樹木倒伏に関するこれまでの研究は，主 に樹木の引き倒し試験の結果から得られた倒伏限界モ一 メントと洪水時に樹木に作用していた外力モーメントと の比較を行い，樹木倒伏の可能性の検討が行われてきた. 八木澤らは実際に流失・倒伏した樹木に作用する外力モ 一メントを算定し，河床材料との関係を示している ${ }^{10,17)}$ そこでは，河床材料が大きい場所における樹木の倒伏限 界モーメントは樹木の引き倒し試験の結果 ${ }^{3}$ より大きく なり，洗掘を受けや寸い河床における倒伏限界モーメン

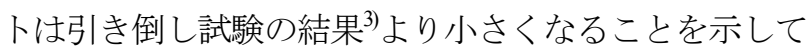
いる ${ }^{10,17)}$.ここでは，太田川で得られた樹木倒伏の実測 データと観測された水面形時系列データを用いた非定常 二次元洪水流・河床変動解析結果により, 倒伏限界モ一 メントを求め, 河道特性との関係について考察する.

\section{a) 樹木に加わる外カモーメントの算定方法}

洪水時には，主流となる領域周辺に位置する樹木群の うち，主流との境界沿いに位置する最前面の樹木が一番 大きな流体力を受けると考えられる. 従って, 最前面の 樹木に作用する流体力から外力モーメントを算出し, 河 道と洪水流の特性の面から樹木の残存及び倒伏箇所につ いて考察する. 外力モーメントの算定には，樹木倒伏が 生じたと考えられる水位ピーク時(午前2:00)の計算結果 を用いる. 平面流速分布から樹木群に作用寸る代表流速 $U$ を求め, 式(2)(3)から流体力を算定する. 代表流速は, 樹木群の最前面における流速を用いる.

$$
\begin{aligned}
& 0-\rho U^{2} A=-F \\
& A=b_{v} h_{c}+h_{b} d_{b}
\end{aligned}
$$

ここで, $\rho:$ 密度, $U$ : 代表流速, $A$ : 樹木の投影 


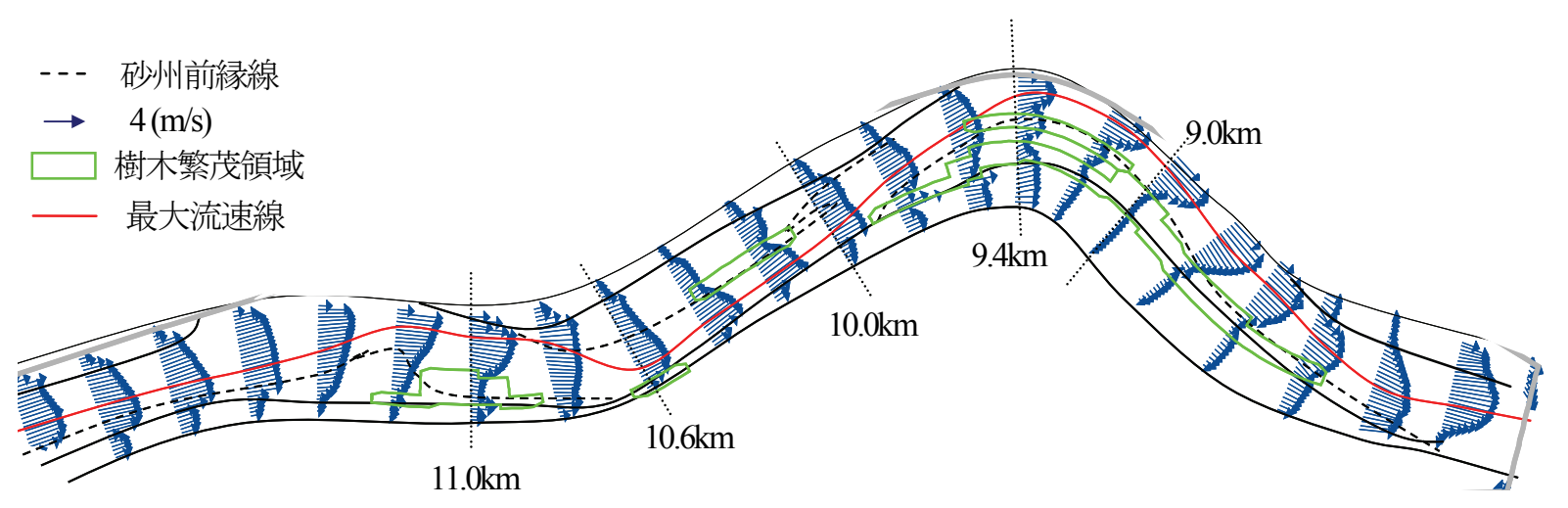

図-22(a) 水位ピーク時(午前 2:00)の流速分布と最大流速線
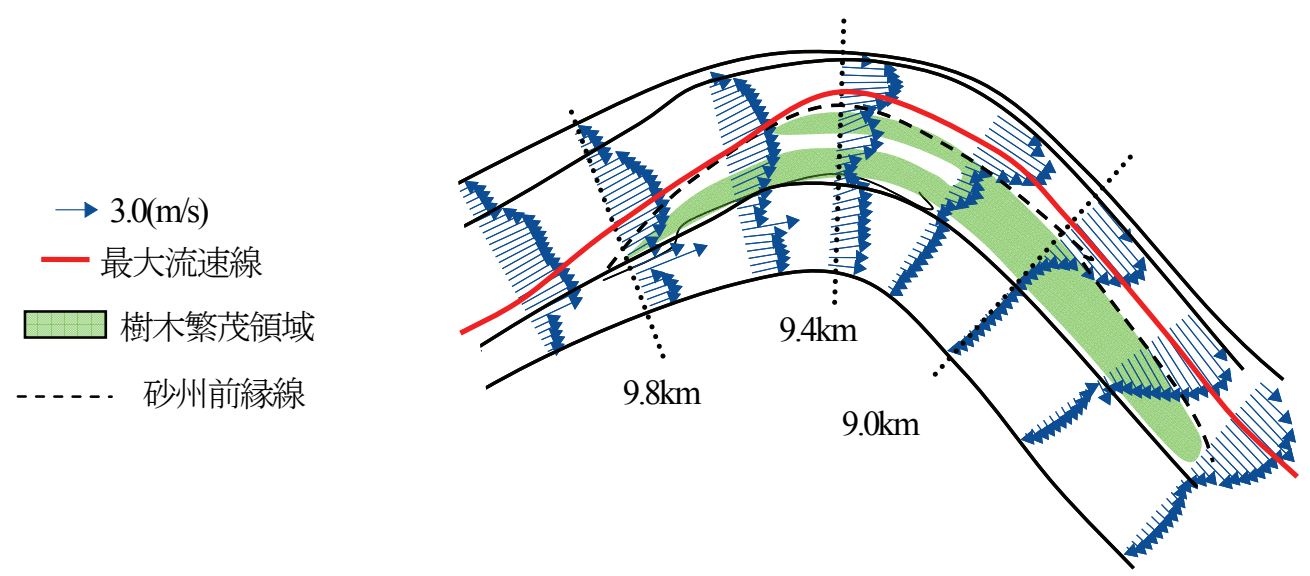

図-22(b) 9.4km蛇行部における水位ピーク時(午前 2:00)の流速分布と最大流速線

面積， $F$ ：樹木が受ける流体力である．樹木群に作用 する力の定義を図-24に示す．樹木群内の流速は小さい とし，樹木の後流域の流速を0と仮定して流体力を算定 している．流体力が樹木の図心に作用するとして，式 (4)より外力モーメントを算定した.

$$
M=F z_{0}
$$

\section{b) 樹木に加わる外カモ一メントと河道特性}

図-25は非定常平面二次元洪水流・河床変動解析によ る水位ピーク時の流速分布と樹木に加わる外力モーメン トMの值を示す．河道の内岸側に樹木が密に繁茂してい るため流速は外岸側の方が大きくなっている. そのため, 外力モーメントは樹木が倒伏した地点の方が樹木の残存 した地点より小さく計算されている. この理由は以下の ように考えられる，倒伏した樹木群は，河床高が高水敷 高より 2〜 $5 \mathrm{~m}$ 程度低い内岸砂州上に位置しており（図一 14），ピーク水位時には主流が内岸寄りを走ることによ り, 樹木群のある砂州河床が洗掘を受け, 相対的に小さ な倒伏モーメントで倒伏が生じたと考えられる. 一方, 樹木が残存した箇所では，図-6(c), 写真-3に示すように 河道の外岸側に根固め工が施工されており, 樹木は根固 め工に根を張り安定しているため, 大きな倒伏モーメン トでも倒伏しなかったと考えられる. この倒伏モーメン トの考察からも, 樹木倒伏の主な要因は河床の洗掘であ

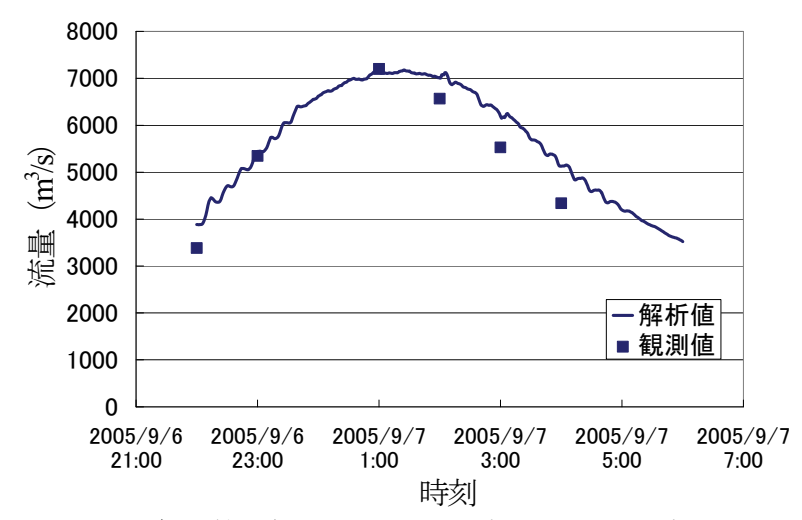

図-23 矢口第一観測所における流量ハイドログラフの 観測結果と解析結果

ることを示している.

図-26は樹木の引き倒し試験から得られた地質別の倒 伏限界モーメントと胸高直径の関係 ${ }^{3}$ を太田川の結果も 含め示している. 渡邊ら ${ }^{13)}$, 八木澤ら ${ }^{10,17)}$ によって示さ れた倒伏モーメントもプロットしている.引き倒し試験 結果では，樹木の根張りと胸高直径の間に相関があるた め ${ }^{32}$ ，横軸の代表長さに胸高直径を用いている.太田川 の検討においても胸高直径を代表長さとすると, 非倒伏 樹木を含め, 全ての樹木が倒伏する領域にプロットされ ることになる. 非倒伏樹木が存在している大きな理由は, 前述の写真-3に示したように樹木は根固め工に根を張り 

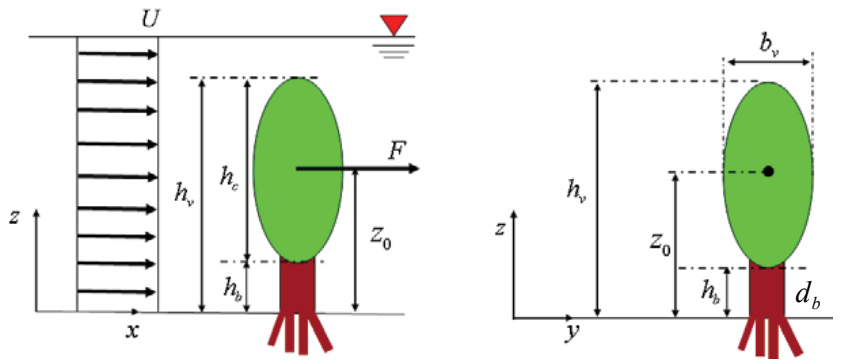

$U$ : 流速, $h_{v}$ : 樹高, $h_{c}$ : 樹冠高, $h_{b}$ : 枝下高, $d_{b}$ : 幹径 $z_{0}:$ 外力の作用高, $b_{v}:$ 樹冠幅, $F:$ 流体力

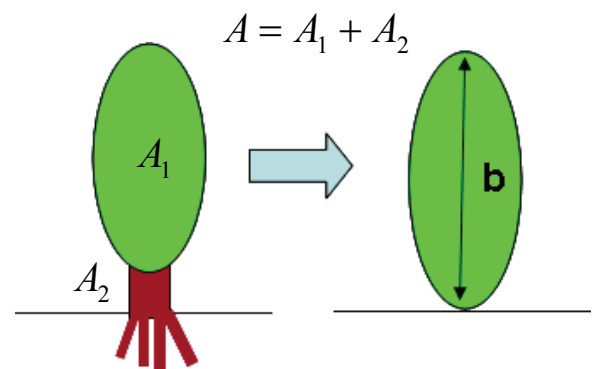

$A_{1}$ : 樹冠部の投影面積, $A_{2}$ : 幹部の投影面積, $A$ : 投影面積, $b$ : 長径

図-24＼cjkstart樹木に作用する力と諸元

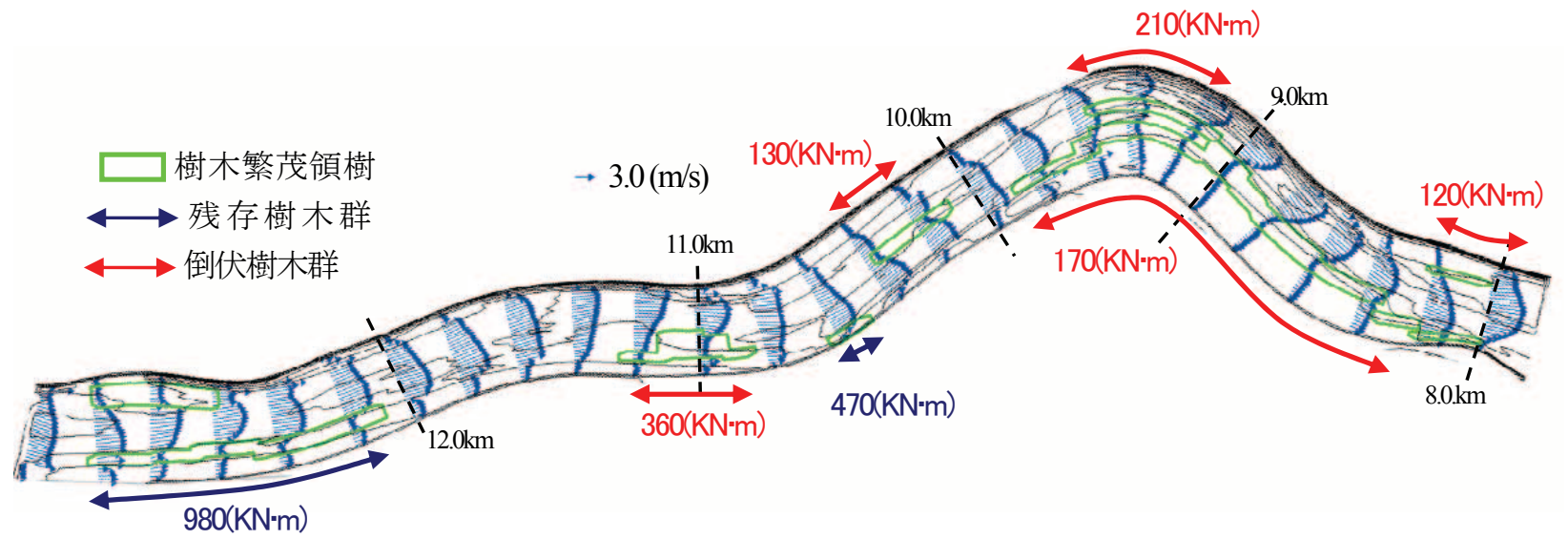

図-25 樹木群に作用寸る水位ピーク時（午前 2:00）における外力モーメントの分布

安定していたためと考えられる.しかし，太田川の検討 結果は, 既往の研究よりも同程度の胸高直径に対し, 倒 伏モーメントが大きく計算されている。 これは，以下の 二つの理由が考えられる. 一つは一本立ちの樹木の倒伏 機構と樹木群の倒伏機構の違いが考えられる. 寸なわち， 樹木群の最前面に位置する樹木は，後流域となる樹木群 内の流速が小さいため，一本立ちの樹木に比べ大きな流 体力が作用したものと考えられる. 二つ目は，流水中に ある樹木群の倒伏，非倒伏を考察する際の樹木の代表長 さの決め方が考えられる. 太田川の場合，写真-6に示寸 ように株立ちの樹木が多く繁茂しており，胸高位置

（1.2m）の直径を評価することが難しい，さらに，既往 の引き倒し試験31,32)では株立ちの樹木ではなく，図-24の ような幹一本からなる樹木を対象としているため，倒伏 モーメントと胸高直径の間の関係を整理しや寸い。一方, 太田川のような群をなしている株立ちの樹木を対象とし た場合，倒伏モーメントと胸高直径の関係を評価するこ とが難しい，このような樹木群が洪水中にある場合の胸 高直径を代表値として考察することの意味について検討 しなければならない．太田川の樹木倒伏の検討では洪水 の流体力が樹木全体に作用するため, 倒伏モーメントを 算定する際に樹木の投影面積が重要な評価要素となる. このため, 代表長さに流体力が作用する投影面積と等価

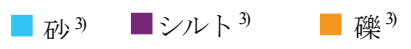

残存樹木 (太田川・投影面積の長径)

—倒伏樹木（太田川・投影面積の長径）

$\square$ 残存樹木（太田川・胸高直径） $\square$ 倒伏樹木（太田川・胸高直径）

- - - 倒伏限界モーメント(データの下限式 $)^{3)}$

一倒伏限界モーメント(データの回帰式) $)^{3)}$

—渡邊らによる倒伏限界モーメント ${ }^{13)}$

— ハリエンジュ流失限界線 ${ }^{16,17)}$

— タチヤナギ流失限界線 ${ }^{10,177}$ ヤマグワの転倒限界線 ${ }^{10,17)}$

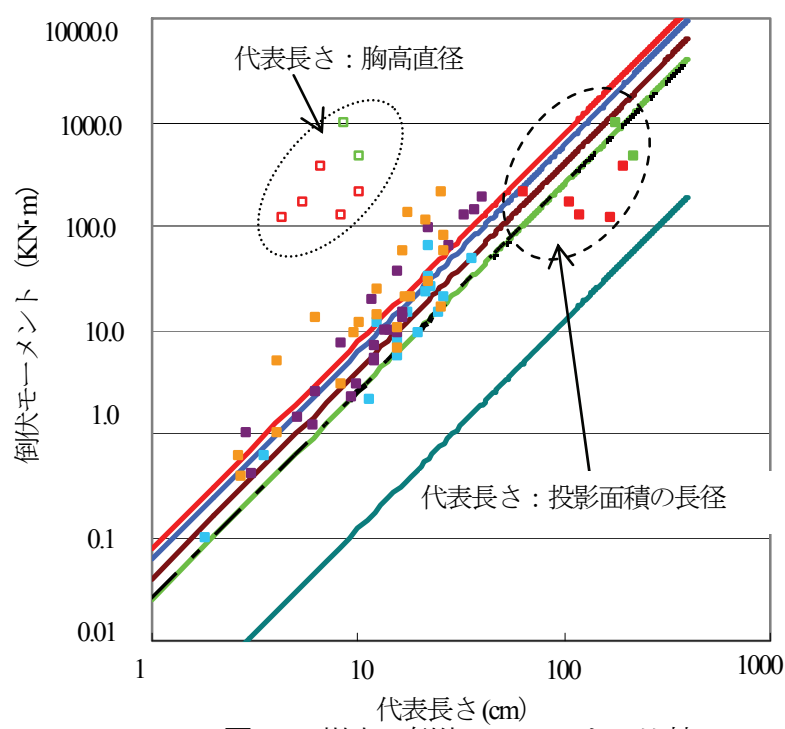

図-26 樹木の倒伏モーメントの比較 


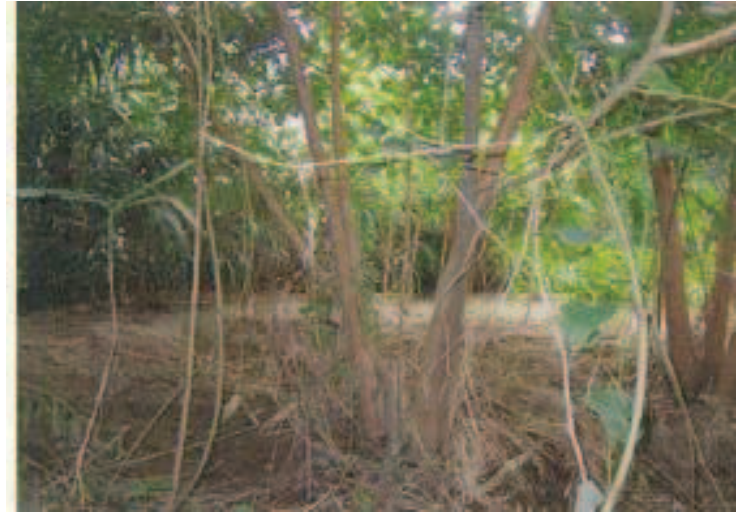

写真-6太田川における株立ちの樹木

な面積の楕円を仮定し，その長径 bを用いて検討を行っ た結果も図-26に示す。代表長さを投影面積の長径とし た場合, 太田川の倒伏モーメントは引き倒し試験結果3) より小さい值を示している.これは陸上での引き倒し試 験と洪水流による倒伏機構の違いが関係していると考え られる. 洪水時樹木周りの河床が洗掘を受けるため, 安 定した河床で行われた引き倒し試験より倒伏モーメント が小さくなったためと考えられる.

以上のことから，倒伏モーメントは個々の樹木倒伏を 説明することができるものの, 洪水流による河床変動や 樹木繁茂の状況が樹木倒伏・非倒伏に影響を及ぼす場合 には，合理的に説明することが難しくなり，状況に応じ た判断が必要になる.

\section{5. 太田川の樹木環境の経年変化と樹木管理への教 訓}

\section{(1)河道内の樹木環境の経年変化}

太田川では昭和18年9月, 昭和47年7月，平成17年9月 とほぼ 30 年周期で約 $7,000\left(\mathrm{~m}^{3} / \mathrm{s}\right)$ 規模の出水が発生し，そ の間に中小規模の洪水が発生している（表-3）．検討区 間では，昭和 27 年〜昭和 35 年に $8.4 \mathrm{~km}-9.6 \mathrm{~km}$ 付近の右岸堤 防の引き堤を行い，現在の堤防法線となっている．河道 内砂州上の樹林化は，平成2年頃から顕著になっている

以下に，昭和47年から平成19年までの砂州河床上の樹 林化と洪水による樹木の破壊を洪水規模との関係で考察 する．図-27は昭和47年7月洪水後に撮影された航空写真 図-28は平成7年航空写真，図-29は平成17年9月洪水後に 撮影された航空写真を示寸. 昭和47年7月時点では砂州 上に樹木がほとんど繁茂していなかった。昭和47年7月 洪水は平成17年9月洪水と同規模 $\left(6,800 \mathrm{~m}^{3} / \mathrm{s}\right)$ であったため, ピーク水位時の主流は内岸寄りを走る複断面的蛇行流れ を呈していたものと考えられ，これより内岸砂州が顕著 に洗掘を受けている（図-27）。この内岸砂州の洗掘位
置は平成17年9月洪水後に撮影された航空写真（図-29） とほぼ一致し，大洪水が発生するとこの地点の内岸砂州 は洗掘を受けることになる. 表-3 より平成5年7月には 中規模の洪水 $\left(3,900\left(\mathrm{~m}^{3} / \mathrm{s}\right)\right)$ を受けているが，樹木はほとん ど被災を受けておらず，内岸砂州も洗掘を受けていない

（図-28）。これは平成5年7月洪水は, 図-7のプロット が示すように洪水の全期間に渡って単断面的蛇行流れを 呈しており，主流が外岸寄りを走ったためである。この ように，中小規模の洪水では内岸砂州上の流速は小さく， 内岸砂州河床はほとんど洗掘を受けず，樹木は倒伏しな かった.

次に平成17年9月洪水により倒伏した樹木の再生状況 について示す. 図-30は平成18年6月撮影航空写真, 図31は平成19年7月に左岸堤防上から撮影した $9.4 \mathrm{~km}$ 付近の 写真である. 洪水後から約1年経過した平成18年6月では, 砂州の前緑線に植生が再生してきている．また，2年経 過した平成19年7月では，大規模な樹木倒伏の見られた $9.4 \mathrm{~km}$ 内岸砂州上で樹木が再生し, 樹高が約 $1 \mathrm{~m} に も$ 達し ている.これは樹木は洗掘を受けたものの, その後の抜 根を行っていないためである.

以上の検討から，太田川の検討区間では，7,000( $\left.\mathrm{m}^{3} / \mathrm{s}\right)$ の大洪水で内岸砂州が洗掘を受け, 内岸砂州上の樹木群 が大規模に倒伏すること，また，倒伏樹木群は2年も経 過すると速やかに再生していることがわかった.

\section{(2)樹木管理への教訓}

平成 17 年 9 月洪水では, ほぼ計画規模の洪水流量が 流れ，検討対象区間の内岸砂州上では，樹木が大規模に 倒伏した. 洪水前後の樹木群や河道断面の変化状況を詳 細に調査・解析した結果から, 河道内樹木群の管理につ いて以下の教訓が得られた。

a)樹木管理が必要な河道区間については，事前に十分調 査検討し, 洪水に備える

太田川は，平成年代に入って河道内に樹木群が顕著に 見られるようになり, 特に $13 \mathrm{~km}$ から $8 \mathrm{~km}$ の河道区間で は洪水の流下能力に影響を及ぼすほど樹木群が繁茂した。 このため, 樹木管理が太田川河川事務所の重要な課題と なり, 平成 15 年には詳細な樹木調查を実施し, どの位 置にどのような樹木が存在するのか等，管理に必要なデ 一タを整えた．さらに，大洪水が発生したとき，流下能 力の視点からこれらの河道内樹木群が倒伏寸るのか，し ないのか，洪水中にどのような挙動をするのかを見極め る必要が生じた．洪水中の樹木群の挙動は，水面形の時 間変化に現れることから，洪水時の水面形の時間変化を 詳細に測定し，それを分析することが必要であるとの考 えの下に，堤防沿いに簡易水位計を多数設置した．これ らの計画にあたっては, 洪水流解析によって何をどの程 度の精度で求めるのかまで意識した洪水流データ収集の 
表-3太田川の主要洪水

\begin{tabular}{|c|c|}
\hline 生起年月日 & $\begin{array}{c}\text { ピーク流量 } \\
\left(\mathrm{m}^{3} / \mathrm{s}\right)\end{array}$ \\
\hline 昭和18年9月20日 & 6700 \\
\hline 昭和20年9月17日 & 5900 \\
\hline 昭和25年9月13日 & 4490 \\
\hline 照和26年10月14日 & 4500 \\
\hline 昭和37年7月5日 & 3134 \\
\hline 昭和38年7月11日 & 3019 \\
\hline 昭和40年7月23日 & 4330 \\
\hline 昭和47年7月12日 & 6800 \\
\hline 昭和51年9月13日 & 5800 \\
\hline 昭和55年8月31日 & 3270 \\
\hline 昭和58年7月23日 & 3800 \\
\hline 昭和60年7月6日 & 3790 \\
\hline 昭和63年7月21日 & 4410 \\
\hline 平成5年7月28日 & 3870 \\
\hline 平成11年6月29日 & 3790 \\
\hline 平成11年9月24日 & 3889 \\
\hline 平成17年9月6日 & 7200 \\
\hline
\end{tabular}

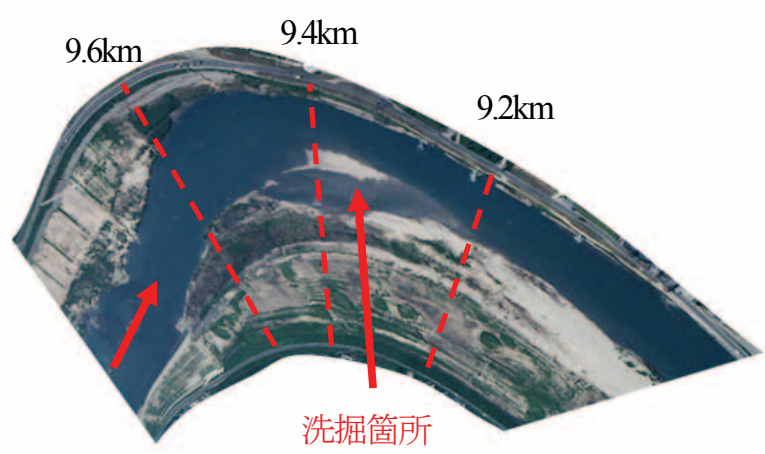

図-27 昭和47年7月洪水後航空写真（昭和47年7月撮影）

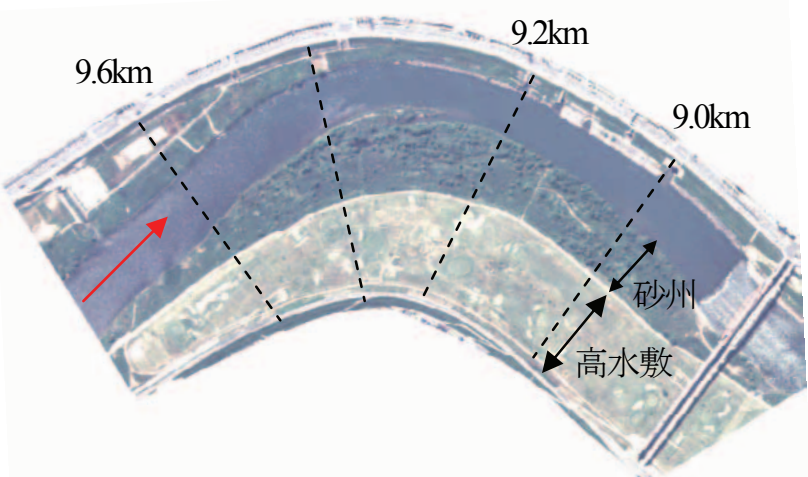

図-28 平成7年航空写真 (平成7年撮影)

ための準備が検討された.

河川の樹木管理という明確な目的の下に，事前に計画 が検討され準備が行われていれば，その後の調査・解析 は，計画の目的にかなうものとなる。，一方，準備の行わ れていない段階で，洪水が突然発生した場合には，検討 すべきデータは十分収集できず，得られたデータのみで の検討に終わり，樹木管理には十分生かせないで終わる ことが多い.

太田川の樹木管理に向けて行われた事前の樹木調査と

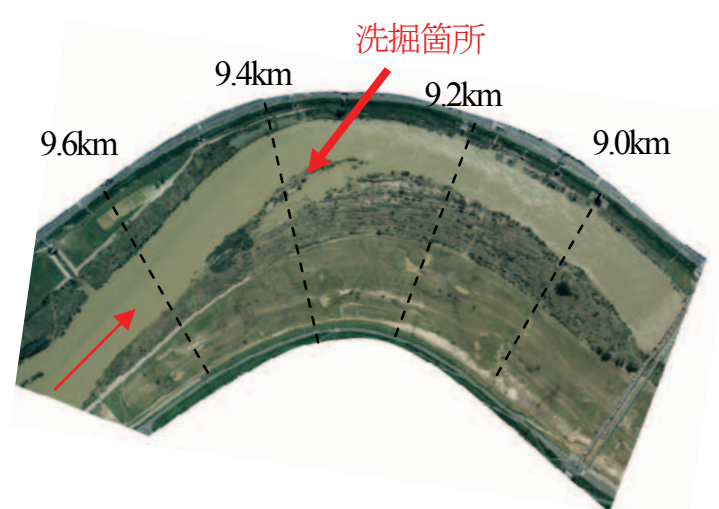

図-29 平成17年9月洪水後航空写真

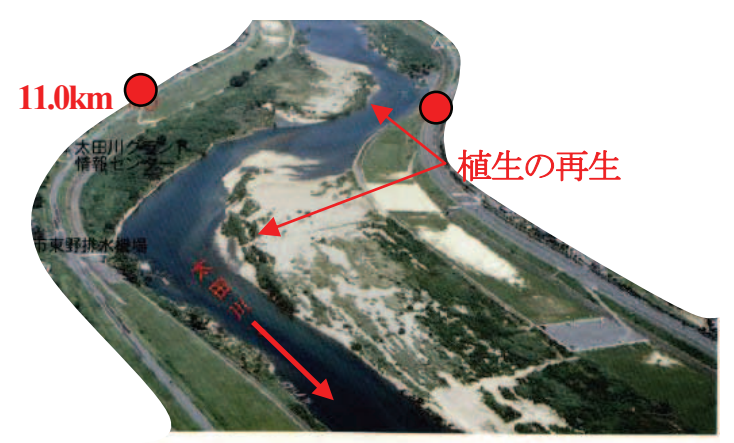

図-30 平成18年6月撮影航空写真（11.0km付近）

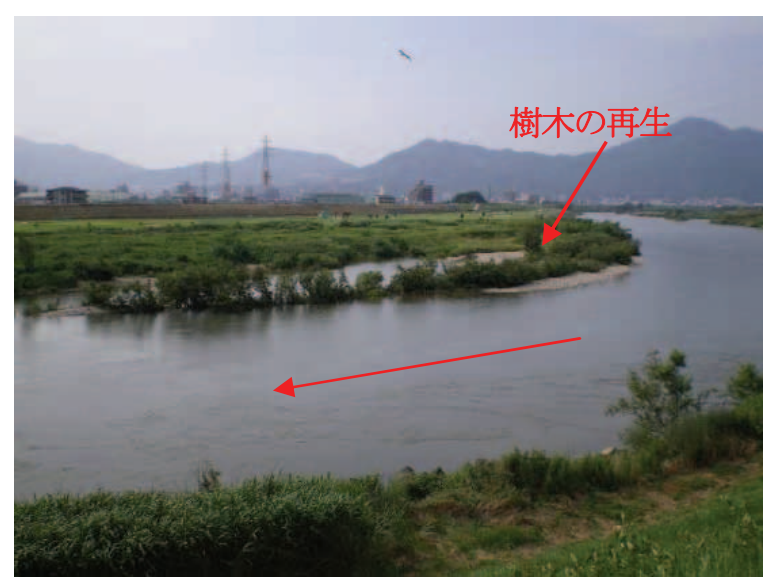

図-319.4km樹木再生状況（平成19年7月撮影）

洪水流観測によって，洪水時の樹木の挙動について重要 な結果を得ることが出来た。得られた技術と解析手法は， 今後同様な課題を有する河川の樹木管理に重要な情報を 提供する.

\section{b) 観測結果の樹木管理への活用}

太田川ではこれらの準備が平成 16 年までに完了した 中で，平成 17 年 9 月に計画規模に匹敵する大洪水が発 生した.

この洪水では，検討対象区間の樹木群は一部倒伏した 


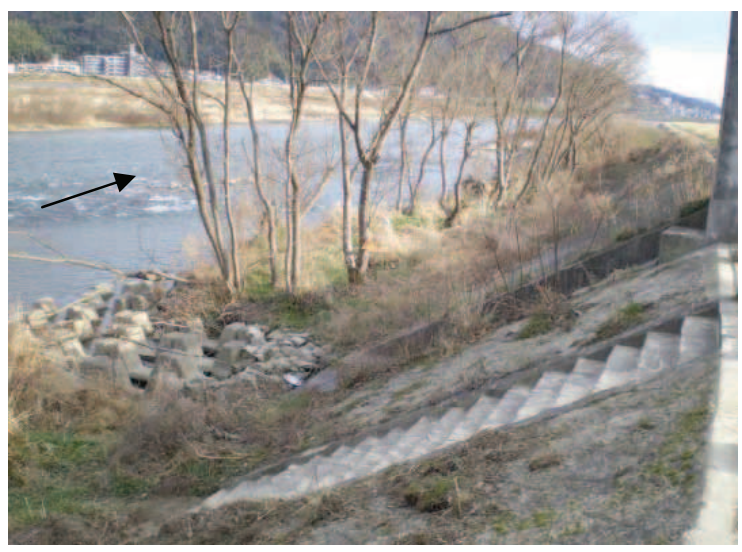

写真-7 外岸根固めブロックとブロック内に根を張り繁茂し た樹木群（10.6km右岸の残存樹木群）

が，結果的に 7,200( $\left.\mathrm{m}^{3} / \mathrm{s}\right)$ の流量が河道を流れた。この事 実は，太田川に平成 17 年洪水前の樹木群が回復したと しても，河道の流下能力はほぼ 7,000( $\left.\mathrm{m}^{3} / \mathrm{s}\right)$ まで保障され ると言えるのであろうか。必ずしもそうは言えないであ ろう。同一の流量でも，河道のどのような線形部分，断 面内のどのような位置に樹木群が繁茂しているかによっ て，樹木の倒伏，非倒伏が分かれてくる．今回検討対象 とした区間では, $7,000\left(\mathrm{~m}^{3} / \mathrm{s}\right)$ 規模で樹木群が多数倒伏し たが，他の河道部分では樹木群が倒伏していない箇所も 見られた．今回の洪水流と樹木倒伏，非倒伏の結果を十 分精査し，計画規模洪水の洪水流量で樹木群が倒伏しな かった場所はどのような河道特性・樹木特性を有するの か，倒伏しなかったことが洪水流の流下能力にどの程度 の影響をもたらしたか等を，水面形の時間変化の観測値 が無い場合には，痕跡水位縦断形を用いた非定常平面二 次元解析から明らかにする必要がある。 さらに，異なる 洪水流量条件についても同様の観測，解析を行い，線形， 断面形，樹木配置条件に対寸る樹木の応答を調心，的確 な樹木管理をするための資料として活用することが大切 である．樹木群が計画規模の洪水流下阻害要因であるこ とが明らかになった場合には，必要に応じて樹木群の伐 採を実行しなければならない，大規模な樹木倒伏が生じ た場合，これらの観測データは樹木伐採後の流況につい て検討する際の資料にもなる．どの場所の樹木群が倒伏 し，その結果として流れ場がどのように変化したのかを 水面形の変化等から明らかにすることは, 樹木管理上の 重要な情報となる.

また，平成17年9月太田川洪水で生じた内岸砂州上の 樹木倒伏と外岸側の樹木群の残存は, 蛇行河川における 湾曲部の内岸側の樹木管理と外岸側の水際部の作り方に ついて重要な知見を与えている. 一般に河道湾曲部の内 岸側には，固定砂州が形成され多くの樹木が繁茂してい る. 平成17年9月洪水では，内岸砂州上の樹木群は大規 模に倒伏したものの，樹木倒伏が生じていなければ洪水

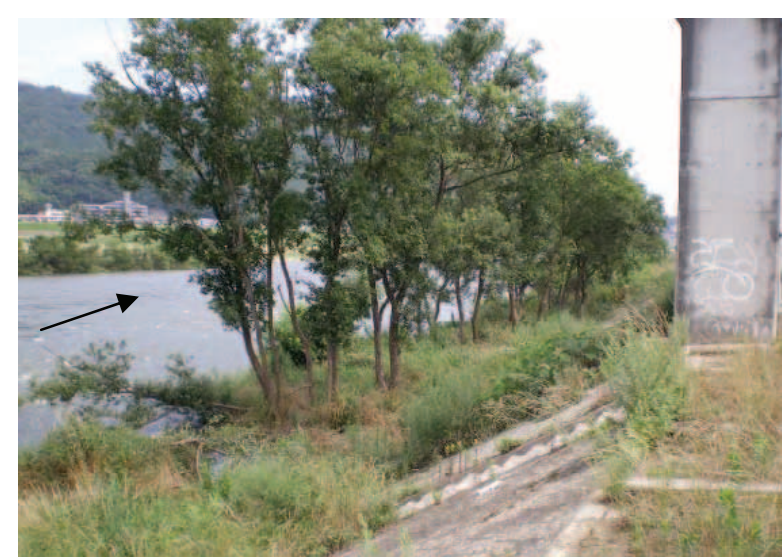

写真-8 根固めブロックと樹木群が一体化し良好な河 川景観を形成している外岸水衝部（10.6km右岸）

流の主流を妨げることにより，水位の堰上げや外岸堤防 際の流速増大を引き起こしていた．内岸砂州及びその上 の樹木群については，計画規模の洪水では砂州が洗掘を 受け，樹木が倒伏することを考慮し，各河川の湾曲部で 河道線形との関係でどのようなことが生じるのかを十分 検討した上で利用・管理を行うことが必要である．湾曲 部の外岸側には, 河床洗掘防止, 河岸保護のために根固 めブロックが施工されることが多い. 平成17年9月洪水 では, $10.6 \mathrm{~km}$ 外岸沿いの根固めブロックが河床洗掘を抑 えており, 変形しないブロックの中に樹木群が根を張つ ているため, 外岸寄りの大きな流速に対しても倒伏・流 失することなく残存した（写真-7）。このことは, 柳群 は根さえ掘れなければ洪水の流体力では簡単に破壊され ないことを示しており, 湾曲した河道外岸水衝部の河岸 侵食・河床洗掘対策と河川景観の両機能を有する安定し た水際作りに護岸ブロックと樹木群の一体的利用は有効 な手段を与えている．樹木群を用いた河岸・法面保護工 については，我が国では柳枝工や挿柳工が伝統的に行わ れており，利根川では明治40年代から行われた河岸への 柳の挿し木により，今日の景観豊かな低水路水際線が形 作られてきている1 ${ }^{1,33)}$. 水衝部の河岸侵食・河床洗掘対 策については，福岡らは，米代川，最上川で高水敷に密 生する柳を樹木群水制として用いる現地試験を行った. この調查研究で得られた結論は，柳水制が水際の保護工 として有効に働くための必須の条件は，河岸・河床が洗 掘されないことであった. そのためには, 根固め工とし て捨石等を設置することが適当であると結論付けた 1,34) 太田川での水衝部にブロックが設置されたことによる安 定な樹木群の残存は, この結論を裏付けている. 写真-8 に示すように外岸水際部の根固めブロックを樹木や草本 類が覆うことで良好な河川景観を生み出している．河川 湾曲部における水衝部の洗掘・侵食対策, 景観豊かな川 づくりに樹木群とブロック群を一体的に用いた今日的河 川技術に仕上げていくことが必要である. 
樹木管理を適正に行うには，治水上からも河川環境上 からも望ましい河道断面形状はどのようなものかを考え， 現地河川等で検討しなければならない. 今後想定される 河道における流量増，樹木管理，河川生態との調和を考 慮し, 総合的に考えた河道のつくり方の調査・研究が急 がれる。

\section{6. 結論}

本研究では，太田川の平成17年9月洪水を対象とし， 複断面蛇行河川における樹木倒伏・破壊機構について次 の検討を行った. 洪水前後の樹木・横断データ等の観測 データと樹木倒伏の関係について調べた.さらに，観測 した水面形の時間変化を用いた流れと河床変動の一体的 推算法により，実際に起きた洪水において洪水中にどの ような流れ場と河床変動が生じていたのかを推定し，樹 木の倒伏機構を力学的に検討した. 以下に本研究におけ る主な結論を示す.

1）樹木が繁茂した区間において，水面形の時間変化を 観測することにより，樹木倒伏の影響が水面形の時間 変化に現れることを示した。 さらに，観測した水面形 の時間変化を用いた洪水中の流れと河床変動の一体的 推算法により，実際の洪水の洪水中の流れ場と河床変 動を求め, 洪水流量ハイドログラフの推算を可能にし た。そして，検討区間ではいつ・どの程度の洪水流量 規模で樹木倒伏が生じたのかを推定した.

2) 洪水前後に観測された横断測量結果から描いた河床 変動コンターより，樹木倒伏が顕著であった区間では 樹木が繁茂している砂州河床が著しい洗掘を受けてお り，砂州河床の洗掘が樹木倒伏の主な要因である．検 討対象区間ではおよそ7,000( $\left.\mathrm{m}^{3} / \mathrm{s}\right)$ 規模の洪水流量で内 岸砂州の洗掘が生じ，大量に樹木群が倒伏した.

3) 水面形時系列観測值を用いた洪水中の流れと河床変 動推算法は，洪水中の流れ場と砂碩砂州上の樹木群の ある箇所の河床変動を，著者らが本研究の目的との関 連で重点的に検討した箇所の洪水流と河床変動につい ては妥当であることを示した. 一方，粗磕や粗石で構 成されている樹木群のある砂州の洗掘については，砂 磒砂州と同程度には再現できておらず，これを説明す るには石硯から構成されている河道の河床変動を表現 できる解析モデルを用いた検討が必要であることを明 らかにした。

4) 樹木の倒伏モーメントによる判定方法は，個々に生 じた樹木倒伏を評価するには課題が多い. 水面形の時 間変化には樹木の影響が現れるため，樹木の繁茂が著 しい区間では水面形の時間変化のデータに基づき，洪 水時の樹木の挙動を検討することが望ましい.
5) 樹木が繁茂した区間で生じた大規模な樹木倒伏の調 査・解析結果は，流下能力に課題を有する区間の樹木 群管理に必要な洪水前後の検討項目を示した。

6) 河川湾曲部外岸の河岸，河床の洗掘対策に，また河 川景観改善の視点から，柳群と侵食対策ブロックを一 体的に用いた河岸保護工法が有効な河川技術となり得 ることを示した。

\section{参考文献}

1) 福岡捷二：洪水の水理と河道の設計法, pp.2-94, pp.141-142, pp.370-391, 森北出版, 2005 .

2) 福岡捷二, 藤田光一: 洪水流に及ぼす河道内樹木群 の水理的影響, 土木研究所報告, 第 180 号の 3 , pp.42-50, 1990.

3) (財)リバーフロント整備センター：河川における樹木 管理の手引き（河川区域内における樹木の伐採・植 樹基準の解説），山海堂， 1999.

4) Darby, S. E.: Effect of riparian vegetation on flow resistance and flood potential, Journal of Hydraulic Engineering, ASCE, Vol.125, No.5, pp.443-454, 1999.

5) 福岡捷二, 渡邊明英, 原俊彦, 秋山正人：水面形の 時間変化と非定常二次元解析を用いた洪水流量ハイ ドログラフと貯留量の高精度推算, 土木学会論文集, No.761/II-67, pp.45-56, 2004.

6) 福岡捷二：洪水流の水面形観測の意義と水面形に基 づく河川の維持管理技術，河川技術論文集，第 12 巻, pp.1-6, 2005.

7) 福岡捷二, 渡邊明英, 田端幸輔, 風間 聡, 牛腸 宏: 利根川・江戸川分派点を含む区間における流量ハイ ドログラフと粗度係数・樹木群透過係数の評価, 水 工学論文集, 第 50 巻, pp.1165-1171, 2006.

8）福岡捷二, 佐藤宏明, 藤澤寛, 大沼史佳 : 洪水流と 河道の樹木繁茂形態に基づく樹木群透過係数と粗度 係数の算定法, 水工学論文集, 第 51 巻, pp.607-612, 2007.

9) 前野詩朗, 渡辺 敏, 藤塚佳晃 : 簡易に得られる植物 特性值を考慮した水理解析モデルの精度向上の提案, 土木学会論文集, No.803/II-73, pp.91-104, 2005.

10) Armanini, A., Rignetti, M. and Grisenti, P.: Direct measurement of vegetation resistance in prototype scale, Journal of Hydraulic Research, Vol.43, No.5, pp.481-487, 2005.

11) Wilson, C. A. M. E., Hoyt, J. and Schnauder, I.: Impact of foliage on the drag force of vegetation in aquatic flows, Journal of Hydraulic Engineering, ASCE, Vol.134, No.7, pp.885-891, 2008.

12) 北川明，島谷幸宏，小栗幸雄：川辺の樹木に関する フィールドワーク, 水理講演会論文集, 第 33 巻, pp.625-630, 1989.

13) 渡邊康玄, 市川嘉輝, 井出康郎：洪水時における河 道内樹木の倒伏限界, 水工学論文集, 第 40 巻, pp.169-174, 1996.

14) 服部 敦, 瀬崎智之, 徳田 真, 近藤和仁, 吉田昌樹, 藤田光一: 植物群落の変化（出水によるハリエンジ ユの倒伏・流失とその後の再萌芽），千曲川の総合 研究一鼠橋地区を中心として一, 河川生態学術研究 会千曲川グループ，（財）リバーフロント整備セン 
ター, pp.587-635, 2001 .

15) 清水義彦, 小葉竹重機, 吉川武志: 出水による八リ エンジュ樹林地の破壊とその規模推定に関する考察, 水工学論文集, 第 46 巻, pp.953-958, 2002.

16）田中規夫，八木澤順治，佐々木寧，福岡捷二：河道 内樹木の洪水破壊形態と破壊限界值の基礎土壤条件 による相違，水工学論文集，第 52 巻，pp.649-654, 2008.

17) 八木澤順治, 田中規夫, 福岡捷二：砂礫州上に繁茂 寸る植生の洪水時流失限界，河川技術論文集，第 14 巻, pp.139-144, 2008.

18）児子真也, 福岡捷二, 後藤岳久 : 樹木の倒伏 - 破壊 を伴う太田川の洪水流の挙動, 第 62 回年次学術講演 会講演概要集, pp.181-182, 2007.

19）後藤岳久, 福岡捷二, 児子真也：洪水流による樹木 の倒伏・破壊と流量ハイドログラフの推算, 第 62 回 年次学術講演会講演概要集, pp.187-188, 2007.

20) 福岡捷二, 小俣篤, 加村大輔, 平生昭二, 岡田将 治：複断面蛇行河道における洪水流と河床変動, 土 木学会論文集, No.621/II-47, pp.1-22, 1999.

21) 岡田将治, 福岡捷二: 複断面河道における洪水流特 性と流砂量・河床変動の研究, 土木学会論文集, No,754/II-66, pp.19-31， 2004.

22) 福岡捷二：土砂環境の変化に対応した洪水流と河床 変動予測技術一実務上の課題と調査・研究の方向性, 河川技術論文集，第 14 巻，pp.1-6，2008.

23) 福岡捷二: 石碟河川の移動床水理の諸問題と解決 の道筋, 第 44 回水工学に関寸る夏期研修会講義集, A コース, pp.1-25, 2008.

24) 鈴木重隆, 中村修也, 川口広司, 福岡捷二：大きな 潮位変動を受ける河道の洪水流れと河床変動一利根 川下流部を例に一, 第 35 回土木学会関東支部技術研 究発表会講演概要集, II-088, 2008.

25) 長田健吾, 福岡捷二：石礫河川の土砂移動機構に着
目した 1 次元河床変動解析法の開発，水工学論文集, 第 52 巻, pp.625-630, 2007.

26) 長田健吾, 福岡捷二：石礫河川の二次元河床変動解 析法に関する研究, 河川技術論文集, 第 15 巻, pp.327-332, 2009.

27) 川口広司, 藤堂正樹, 福岡捷二：水面形時系列デー 夕に基づく交互砂州平均河床高の時間变化及び流量 ハイドログラフの解析, 水工学論文集, 第 53 巻, pp.751-756, 2009.

28) 後藤岳久, 福岡捷二：太田川洪水流による砂州の洗 掘と樹木倒伏機構に関する研究，水工学論文集，第 53 巻, pp.787-792, 2009.

29) 土木学会水理委員会：水理公式集〔平成 11 年版〕, 丸善, 1999.

30）芦田和男, 江頭進治, 劉炳義：蛇行流路における流 砂の分級および河床変動に関する数值解析, 水工学 論文集，第 35 巻，pp.383-390，1991.

31) Osada, K. and Fukuoka, S.: Development of onedimensional bed variation analysis methods focused on the mechanism of sediment transport in stony-bed river, Advances in Hydro-Science and Engineering, ICHE, Vol.8, pp.1387-1396, 2008.

32) 苅住 曻：新装版樹木根系図説, pp.101-111, 誠文堂 新光社, 1988 .

33) 白井勝二, 福岡捷二：利根川における護岸・水制の 変遷とその今日的役割, 水工学論文集, 第 46 巻, pp.505-510, 2002.

34) 福岡捷二, 樺沢孝人, 斉藤潤一, 布施泰治, 渡邊明 英，大橋正嗣：柳水制の試験施工とその機能の現地 調査, 水工学論文集, 第 42 巻, pp.445-450, 1998.

(2009.5.7 受付)

\section{MECHANISM OF VEGETATION DESTRUCTION DUE TO A FLOOD FLOW AND APPLICATION TO VEGETATION MANAGEMENTS IN A COMPOUND MEANDERING RIVER}

\section{Takahisa GOTOH, Shoji FUKUOKA, Shinya NIGO and Jun NAKASUKA}

In the Ota River, we had investigated kind, positions and properties of vegetations and prepared to measure temporal changes in water surface profiles of a flood. In 2005, the largest flood in the past 50 years occurred in the river. Vegetations on sandbar formed inner bank side were destructed by the flood flow. Unsteady 2D analysis of flood flow and bed variation using observed temporal changes in water surface profiles demonstrate the flood flow characteristics, bed variations and mechanism of vegetation destruction. Vegetation destruction was caused by the bed scouring of sandbar. The concept and means for the vegetation management are derived from the present investigation. 